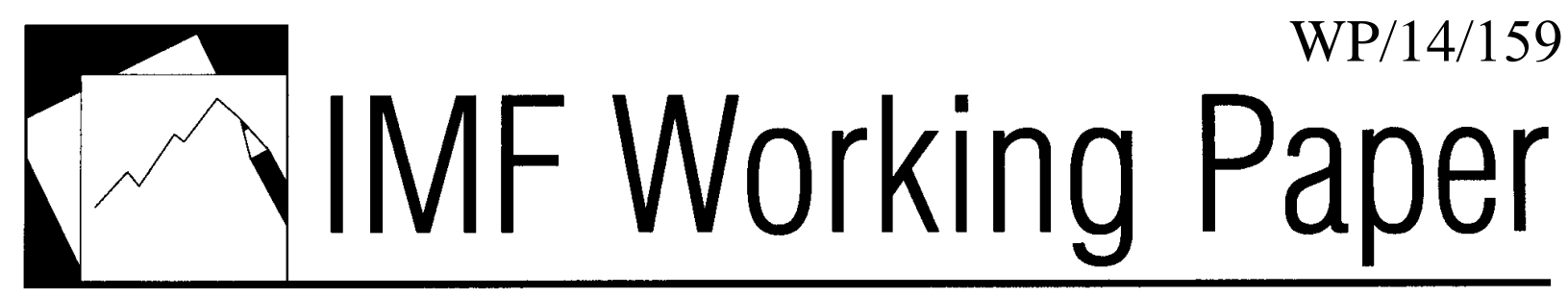

\title{
Introducing a Semi-Structural Macroeconomic Model for Rwanda
}

Luisa Charry, Pranav Gupta, Vimal Thakoor 


\title{
IMF Working Paper
}

Research Department, Strategy, Policy and Review Department, and African Department

\author{
Introducing a Semi-Structural Macroeconomic Model for Rwanda \\ Prepared by Luisa Charry, Pranav Gupta, Vimal Thakoor*
}

Authorized for distribution by Andrew Berg, Catherine Pattillo and Paulo F.N. Drummond

August 2014

\section{This Working Paper should not be reported as representing the views of the IMF.}

The views expressed in this Working Paper are those of the author(s) and do not necessarily represent those of the IMF, IMF policy or DFID*. Working Papers describe research in progress by the author(s) and are published to elicit comments and to further debate.

\begin{abstract}
We develop a simple semistructural model for the Rwandan economy to better understand the monetary policy transmission mechanism. A key feature of the model is the introduction of a modified uncovered interest parity condition to capture key structural features of Rwanda's economy and policy framework, such as the limited degree of capital mobility. A filtration of the observed data through the model allows us to illustrate the contribution of various factors to inflation dynamics and its deviations from the inflation target. Our results, consistent with evidence for other countries in the region, suggest that food and oil prices as well as the exchange rate have accounted for the bulk of inflation dynamics in Rwanda.
\end{abstract}

JEL Classification Numbers: E47, E52, O23

Keywords: Monetary Policy, Monetary Transmission Mechanisms, Low Income Countries Authors’ E-Mail Address: 1charry@imf.org, pgupta@imf.org, jthakoor@imf.org

\footnotetext{
* This working paper is part of a research project on macroeconomic policy in low-income countries supported by the U.K.'s Department for International Development (DFID). Masafumi Yabafara participated in earlier stages of the project. We would like to thank Andrew Berg, Paulo Drummond, Rafael Portillo and seminar participants at the IMF's African Department for valuable comments. Fan Yang provided valuable research assistance. All errors remain ours.
} 


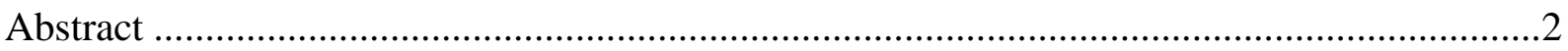

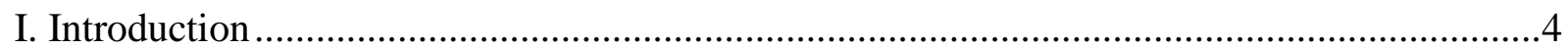

II. An Overview of Rwanda's Economy and Monetary Policy Regime ...................................6

III. The Model: Outline, Calibration, Filtering, and Forecast Exercise .................................. 9

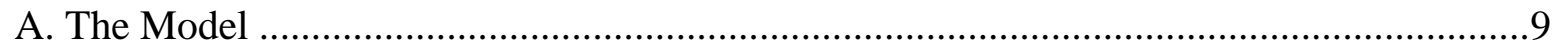

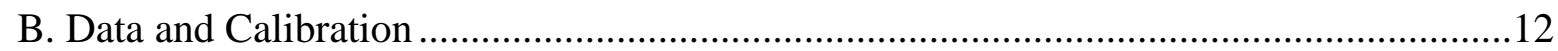

IV . Filtering Rwandan Data through the Model............................................................. 15

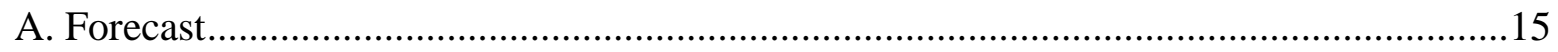

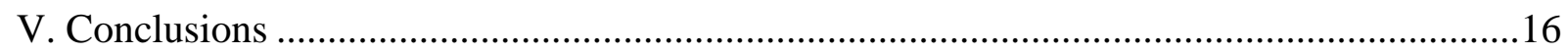

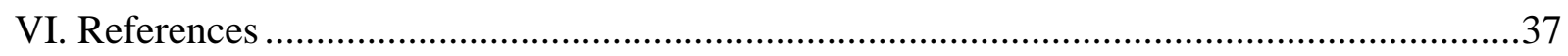

\section{Tables}

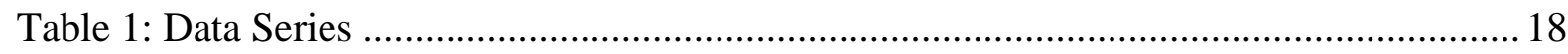

Table 2: Calibration................................................................................................ 19

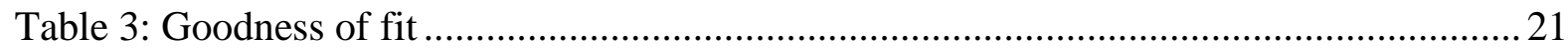

\section{Figures}

Figure 1. Rwanda: Selected Economic Indicators, 2006-2013 ........................................ 7

Figure 2: Impulse Response Functions I (Demand Shock) .............................................. 22

Figure 3: Impulse Response Functions II (Supply Shocks: Core, Food, Oil Inflation) .......... 23

Figure 4: Impulse Response Functions III (Interest Rate Shock) .................................... 24

Figure 5: Real Exchange Rate Trend and Gap ........................................................... 25

Figure 6: Real Interest Rate Trend and Gap.................................................................. 26

Figure 7: Output Trend and Gap .............................................................................. 27

Figure 8: Shock Decomposition of Headline Inflation (YoY) ........................................ 28

Figure 9: Shock Decomposition of Core Inflation (YoY) ..............................................29

Figure 10: Shock Decomposition of Food Inflation (YoY) ........................................... 30

Figure 11: Shock Decomposition of Oil Inflation (YoY) ............................................ 31

Figure 12: Shock Decomposition of the Output Gap .................................................... 32

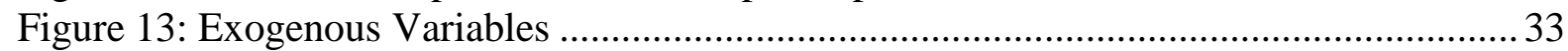

Figure 14: In-sample Forecast of the Main Variables ......................................................... 34

Figure 15: Out-of-sample Forecast of the Main Variables................................................ 35

Figure 16: Out-of-sample Forecasts of Main Variables- Continued .................................... 36 


\section{INTRODUCTION}

Despite the different macroeconomic frameworks in place, many Sub-Saharan African (SSA) countries have successfully re-anchored inflation expectations. This is largely driven by the increasing recognition among policymakers that a stable macroeconomic environment, including well anchored inflation expectations, can be a significant contributor to growth. Inflation in most of SSA however remains vulnerable to food and oil price shocks.

In this context, after facing some challenges in the conduct of monetary policy ${ }^{2}$ and to further legitimize their commitment to a low and stable inflation, central banks of the East African Community (EAC) have embarked on gradually updating their monetary policy frameworks. The main changes include allowing greater exchange rate flexibility, enhancing the role of policy rates in the signaling of the policy stance, announcing inflation targets, and introducing forwardlooking elements in policy formulation and communication strategies. As part of this process, efforts have also been undertaken to better understand the transmission channels of monetary policy to real economic activity and prices. This paper contributes to this effort by introducing a macroeconomic model for Rwanda to aid the understanding of the monetary policy transmission mechanism.

The National Bank of Rwanda (NBR) has been working on strengthening its monetary policy framework. While it continues to target broad money, it has also been placing greater emphasis on injecting greater flexibility in the system to improve the transmission mechanism. The NBR has recently implemented a series of measures aimed at absorbing excess liquidity and improving the interbank market (IMF, 2013c). At the same time, the NBR has gone to great lengths to establish its commitment to low and stable inflation by putting in place an informal target of 5 percent. In a bid to better understand the transmission mechanism, the NBR has been working on developing models, seeking to inform the decisions of the monetary policy committee (MPC).

One of the dimensions through which the understanding of the transmission mechanism can be enhanced is through the introduction of a semi-structural macroeconomic model that links the monetary policy stance to economic activity and inflation. Such a model can then be integrated into a wider set of processes and tools (a Forecasting and Policy Analysis System, FPAS) to prepare coherent macroeconomic forecasts, perform scenario analysis, and inform the monetary policy formulation process. The model introduced here is a rational expectations New-Keynesian model, similar to models used in central banks around the world. The model consists of four basic behavioral equations: an IS curve (aggregate demand), which relates monetary policy and real economic activity; a set of Phillips curves (aggregate supply) that link economic activity and inflation; a monetary policy rule that describes the response of the central bank to deviations of inflation from the target and the phase of economic activity.

\footnotetext{
${ }^{2}$ See, for example, Andrle, Berg, Morales, Portillo, and Vlcek (2013) and Berg, Charry, Portillo, and Vlcek (2013).
} 
A key feature of the model is the introduction of a modified uncovered interest parity condition (UIP), which describes exchange rate dynamics. This modification to the UIP condition seeks to capture key structural features of Rwanda's economy and policy framework, such as the rather closed nature of the capital account, the shallow and nascent financial system, and the existence of dual targets on both inflation and the nominal exchange rate. ${ }^{3}$

The model is calibrated to reflect a set of stylized facts of the Rwandan economy, specially the heavy reliance of monetary policy on a stable exchange rate. A filtration of the last ten years of observed data trough the model allows us to determine the contribution of various factors to inflation dynamics and its deviations from the inflation target of 5 percent. In particular, we are able to dissect the contribution of food and oil prices to inflation. Our results, consistent with evidence for other countries in the region, suggest that food and oil price shocks have accounted for the bulk of inflation dynamics in Rwanda, particularly in 2008 and 2011. Fluctuations in food prices have the greatest impact on inflation, while the impact of inflation from international oil price changes is somewhat lower. This can be explained by the fact that the there is only partial pass-through from international prices to the domestic pump price structure, which is administratively updated on a regular basis to mitigate their impact.

The filtration exercise also enables us to show that there have been periods when the monetary policy stance has been more accommodative than warranted, most significantly in 2008 and 2011, and this in turn has contributed to inflation deviating from its target. In 2008 monetary policy was significantly looser than required, given the inflationary developments. In 2011, while policy was looser for a longer duration, the magnitude was smaller compared to 2008.

We also disentangle the contribution of the exchange rate to inflation. We find that exchange rate developments were a significant contributor to inflation in 2008, as was the depreciation of the exchange rate in the second half of 2012 in response to a suspension of foreign aid flows. The latter impact was however mitigated by favorable food price developments. The model thus enables a clear identification of the factors contributing to inflation, both from domestic and external factors, as well as those which are policy induced. Furthermore, what the exercise shows is that properly tailored structural models can provide useful insights even when the data is noisy or scarce, financial markets underdeveloped, and regimes are changing.

The rest of this paper is organized as follows. Section II presents an overview of the Rwandan economy and the implementation of monetary policy. The model, and the results of the filtering and forecasting exercises are presented in Section III. Section IV discusses the authorities' conduct of monetary policy in light of the findings from the model. Section $\mathrm{V}$ concludes.

\footnotetext{
${ }^{3}$ See, for example, Berg et al (2013).
} 


\section{An Overview of RWanda's Economy And Monetary Policy Regime}

Rwanda's economy has come a long way over the past two decades. Judicious economic policies, coupled with ample donor support, have allowed the economy to sustain a real annual growth of around 8 percent over the past decade. The sectors that have contributed most to growth are agriculture and services. Targeted policies and improving productivity have increased the contribution of the agricultural sector, which accounts for over 30 percent of GDP and 70 percent of employment (National Institute of Statistics of Rwanda). High public investment and a deliberate policy to stimulate private sector credit growth have also supported the construction and services sectors. While achieved from an initial low base, this sustained growth has enabled the country to make significant inroads in the fight against poverty, as real GDP per capita increased from around US\$200 in 2001 to US\$660 in 2013.

Foreign grants have traditionally been a major component of budgetary resources but the authorities would like to reduce Rwanda's aid reliance and foster greater domestic revenue mobilization. Rwanda's trade balance has been continuously in deficit, largely attributable to the narrow export base dominated by low value products like coffee and tea. Mineral exports are increasing, although the sector is not yet operating at full potential. Despite exhibiting strong Doing Business indicators, FDI flows are yet to materialize on a significant scale. Debt relief coupled with prudent fiscal policies have contained external debt to under 25 percent of GDP. In 2013, Rwanda tapped the international capital markets for the first time in its history, with the issuance of a US\$400 million euro bond.

The objectives of the NBR include maintaining inflation at single digits, while supporting growth. Accordingly, the NBR targets an inflation rate of 5 percent. Monetary policy has been formulated in the context of challenging, and at times difficult, domestic and external environments. In particular, food and oil price shocks have played an important role in inflation dynamics. Also, the economy has been subject to significant demand shocks stemming from the global financial crisis in 2009. The suspension of aid flows in 2012 has added an additional dimension to the policy formulation challenges. Reserves were initially used to cushion the impact of the shock on the economy. However, as imports cover neared four months, the authorities allowed for greater flexibility in the exchange rate, which has depreciated by over 12 percent since 2012.

Inflation, while volatile, has been contained at single digits (Figure 1). Food and fuel prices have substantial impacts on headline inflation. Food accounts for 35 percent of the CPI in Rwanda. About 85 percent of the food basket is sourced locally, while the rest is imported. As a country that fully relies on imported oil, Rwandan inflation is also exposed to changes in international fuel prices, albeit the impact can be delayed as local fuel prices are subject to administrative controls and the pass-through may not be immediate. In the CPI statistics, fuel is included in the transportation component, which accounts for 12 percent of the basket. 
Figure 1. Rwanda: Selected Economic Indicators, 2006-2013
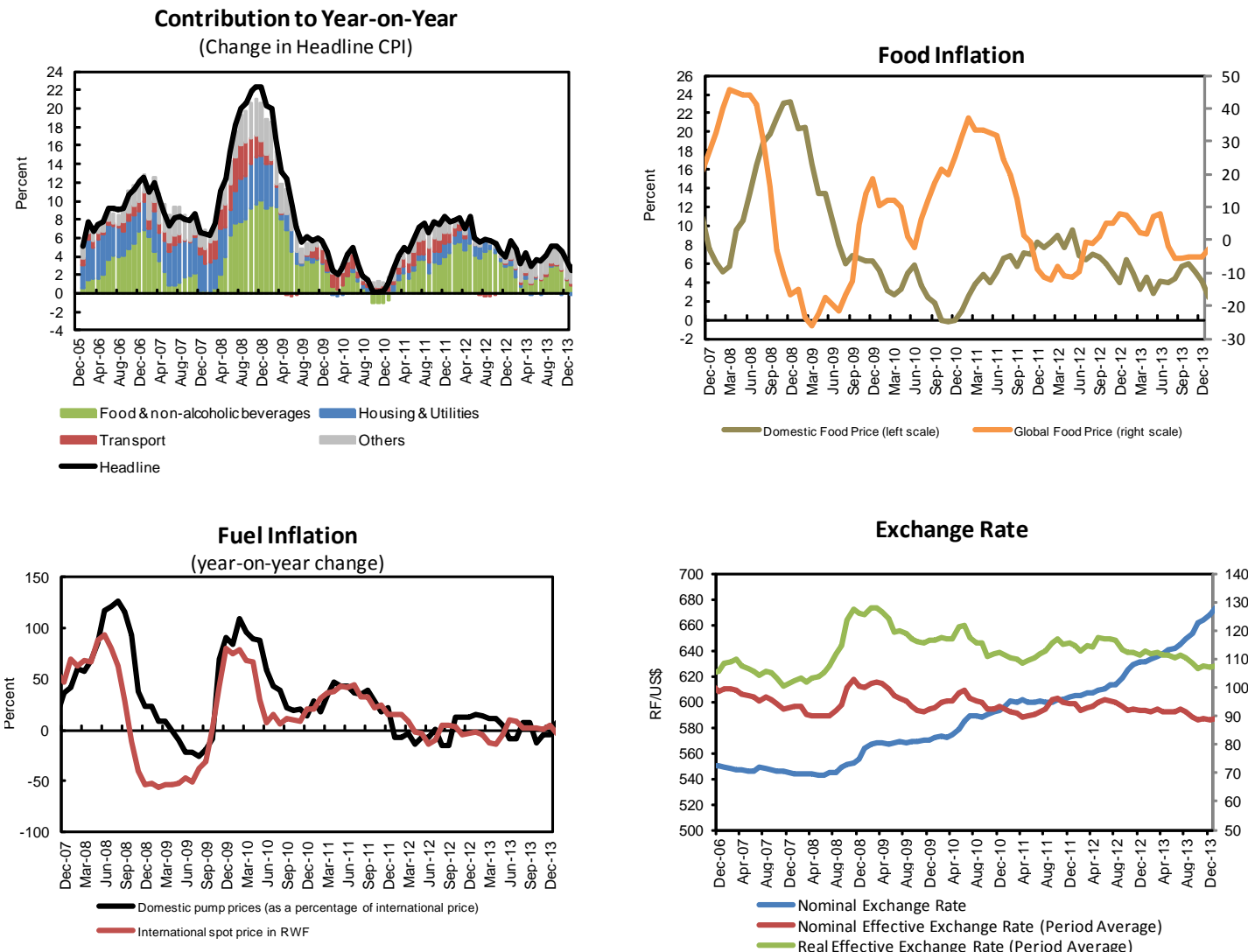

Exchange Rate

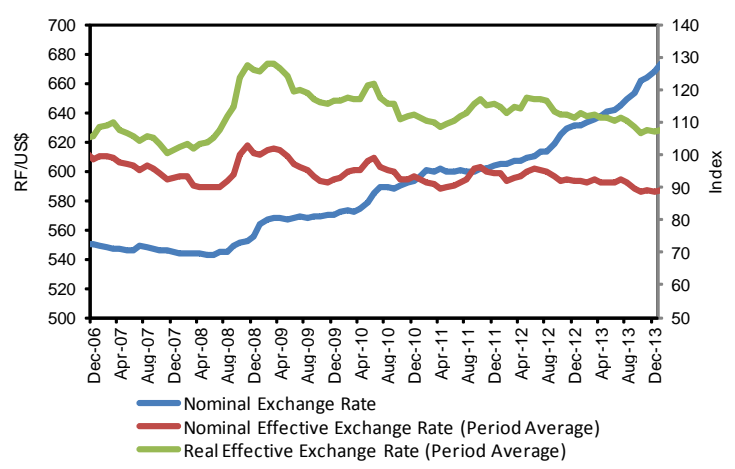

Monetary Indicators

(percent of GDP)
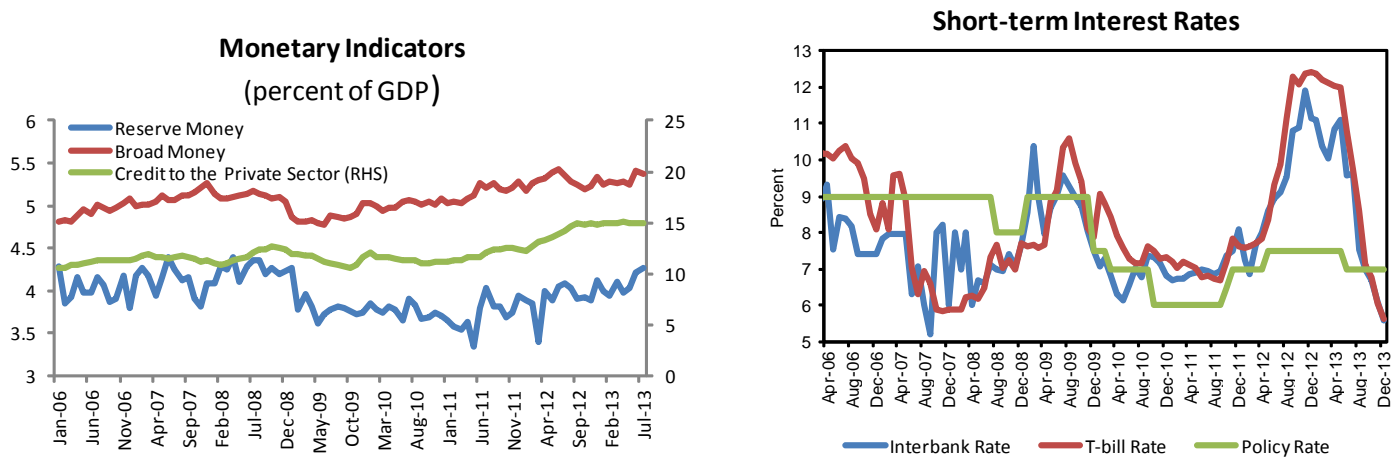

Reserves
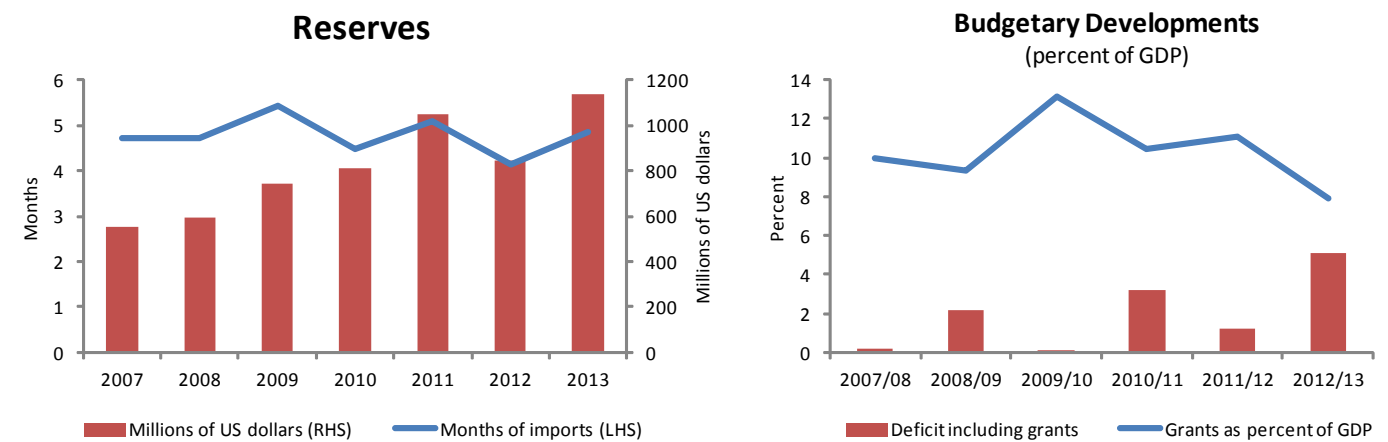

Source: IMF staff based on authorities' data. 
The NBR conducts policy in the context of a flexible monetary targeting framework, with reserve money used as the operational target and broad money (M3) as an intermediate target. An array of instruments is used to manage liquidity, including reserve requirements, open market operations, standing facilities, and foreign exchange operations. The NBR has also increasingly relied on its policy rate - the Key Repo Rate (KRR) - to signal its monetary policy stance. Since the introduction of the KRR in 2008, the NBR conducts repo transactions with commercial banks to navigate interbank rates in a corridor around the KRR. However, the coexistence of both quantity and price targets has, on occasions, led to inconsistent signaling of the policy stance. ${ }^{4}$

Monetary policy implementation, while improving, remains challenging. A gradual shift to a quarterly average for reserve money, within a band, has provided the authorities greater latitude in the conduct of their monetary policy operations. The slow response of the KRR in response to changing monetary conditions and market developments has however undermined its signaling role and its effectiveness in the transmission mechanism. The authorities have had at times needed to have recourse to moral suasion to affect market rates, or take administrative measures - for example, by not fully passing through international oil price changes - to contain inflation.

The NBR is taking measures to improve the transmission of monetary policy and ensure greater relevance for the policy rate. To better absorb liquidity, the NBR has started issuing longer term instruments, and reactivated the secondary market to support the development of an active interbank market. The NBR is also bolstering its communication strategy with market participants to promote a better understanding of monetary policy decisions and to guide expectations formation. The publication of the quarterly inflation report goes in this direction.

The Rwandan authorities have traditionally favored a stable exchange rate. The NBR has intervened regularly to maintain the currency within a narrow band of the official rate. However, the determination of the market exchange rate suffers from some structural issues. The interbank market remains shallow, dominated by the central bank. To foster greater exchange rate flexibility, the authorities introduced an exchange rate corridor system in March 2010 and committed to intervening in the market only to smoothen out temporary volatility. Following the aid shock in 2012, and in a bid to preserve reserve levels and contain pressures in the forex market, the NBR has allowed greater exchange rate flexibility. The currency has depreciated by over 12 percent since. Rwanda's de facto exchange rate classification has since been revised from crawl-like to other managed arrangement. The de jure exchange rate arrangement is classified as floating (IMF, 2013a).

\footnotetext{
${ }^{4}$ For example, in late 2008 and responding to a liquidity squeeze the NBR lowered reserve requirements and introduced new credit facilities for commercial banks. However, at the same time, the NBR increased the KRR to promote deposits.
} 


\section{The Model: Outline, Calibration, Filtering, And Forecast EXercise}

\section{A. The Model}

The model introduced here is a rational expectations New-Keynesian model, similar to those in place in central banks around the world. The model consists of four blocks: aggregate demand, aggregate supply, links with the rest of the world through arbitrage conditions and a monetary policy rule. In terms of general notation, for any given variable $x$, a bar $(\bar{x})$ denotes that variable's trend or long-run value, and a gap term added to the variable (xgap) denotes deviations from trend. The model is specified for quarterly frequencies, a delta $(\Delta)$ in front of the variable indicates, except for inflation rates which are denoted by $\pi$ and correspond to quarter over quarter annualized seasonally adjusted changes. Finally, an asterisk * denotes a foreign variable and ss subindexes stand for steady state values. ${ }^{5}$ Behavioral equations also include autoregressive components to better match the properties of the data.

\section{i. Aggregate Demand}

Equation 1 describes the behavior of deviations of output from trend (the output gap), where ygap is the output gap, rmci is the real monetary conditions index (an overall indicator of the monetary policy stance, which is a weighted average of the deviation of the real interest rate and real exchange rate from their trends), ygap* is the US output gap, rgap is the real interest rate gap and zgap is the real exchange rate gap. ${ }^{6} \varepsilon^{\text {ggap }}$ represents a shock or innovation to domestic aggregate demand which picks up non-modeled effects. The real interest rate is the ex-ante interbank rate deflated by headline inflation.

$$
\begin{gathered}
\operatorname{ygap}_{t}=\beta_{1} \operatorname{ygap}_{t-1}-\beta_{2} r m c i_{t-1}+\beta_{3} \text { ygap }_{t}^{*}+\varepsilon_{t}^{\text {ygap }} \\
r m c i_{t}=\left(1-\beta_{4}\right) \operatorname{rgap}_{t}-\beta_{4} z_{\text {gap }}
\end{gathered}
$$

\section{ii. Aggregate Supply}

To better capture the effects of supply shocks on inflation dynamics and the conduct of monetary policy we introduce behavioral processes for core, food and fuel inflation. Core inflation ( $\pi^{\text {core }}$ ) dynamics evolve according to Equation 3. Here, the lagged term in the Phillips curve captures the backward-looking expectations of agents based on learning, imperfect credibility of the central banks, or indexation. Whereas $E_{t} \pi_{t}$ stands for headline inflation expectations and is defined as a function of lagged and future inflation. ${ }^{7} \mathrm{rmc}$ denotes the real marginal costs, given by a weighted

\footnotetext{
${ }^{5}$ For simplicity we use US variables to proxy for the rest of the world.

${ }^{6}$ The nominal exchange rate is defined as units of domestic currency (Rwandan Franc) per US dollar. The real exchange rate is a bilateral rate vis a vis the US dollar.

${ }^{7}$ This specification allows us to capture potential second-round effects of supply shocks on core inflation.
} 
average of the real exchange rate gap (zgap) and the output gap (ygap). The real exchange gap reflects the effect of imported goods' prices on inflation while the output gap captures excess aggregate demand pressures. Once again, $\varepsilon^{\text {core }}$ stands for shocks coming from excluded factors.

$$
\begin{gathered}
\pi_{t}^{\text {core }}=\lambda_{1} \pi_{t-1}^{\text {core }}+\left(1-\lambda_{1}\right) E_{t} \pi_{t}+\lambda_{2} r m c_{t}+\varepsilon_{t}{ }^{\text {core }} \\
E_{t} \pi_{t}=\alpha \pi_{t-1}+(1-\alpha) \pi_{t+1} \\
r m c_{t}=\theta\left(\text { ggap }_{t}\right)+(1-\theta) \operatorname{ygap}_{t}
\end{gathered}
$$

Food inflation dynamics $\left(\pi^{\text {food }}\right)$, in turn, are represented by Equation 6. Similarly to core inflation, food inflation is explained by its past level, inflation expectations and excess aggregate demand pressures. Additionally, the $\hat{\varphi} f o o d$ term captures price pressures arising from changes in international food prices ( $\pi^{\text {food* }}$ ) relative to domestic food prices. Here $\Delta s$ stand for changes in the nominal exchange rate and $\Delta \overline{z_{t}}$ denote changes in the trend value of the real exchange rate and $\varepsilon^{\text {food }}$ is a perturbation term.

$$
\begin{gathered}
\pi_{t}^{\text {food }}=\lambda_{3} \pi_{t-1}^{\text {food }}+\left(1-\lambda_{3}\right) E_{t} \pi_{t}+\lambda_{4} \hat{\varphi} \text { food }_{t}+\lambda_{5} \text { ygap }_{t}+\varepsilon_{t}^{\text {food }} \\
\hat{\varphi} \text { food }_{t}=\left(\Delta s_{t}+\pi_{t}^{\text {food* }}-\pi_{t}^{\text {food }}-\Delta \overline{z_{t}}\right) / 4
\end{gathered}
$$

The specification for oil inflation $\left(\pi^{o i l}\right)$ has a similar structure as the one for core and food inflation (Equation 8).

$$
\pi_{t}^{o i l}=\lambda_{6} \pi_{t-1}^{o i l}+\lambda_{7} E_{t} \pi_{t}+\left(1-\lambda_{6}-\lambda_{7}\right)\left(\pi_{t}^{o i l *}+\Delta s_{t}-\Delta \overline{z_{t}}\right)+\varepsilon_{t}^{o i l}
$$

Finally, headline inflation is defined as the weighted average of core, food and oil (Equation 9).

$$
\pi_{t}=w_{1} \pi_{t}^{c o r e}+w_{2} \pi_{t}^{\text {food }}+\left(1-w_{1}-w_{2}\right) \pi_{t}^{o i l}
$$

\section{iii. Exchange Rate Determination}

The block that models the links with the rest of the world is comprised by a set of arbitrage conditions. We introduce a modified uncovered interest rate parity condition to simulate nominal exchange rate dynamics in Rwanda (Equation 10), where $s_{t}$ is the nominal exchange rate, $s_{t}{ }^{T}$ is the target exchange rate, $i$ and $i^{*}$ are the Rwandan interbank rate and the US Federal Funds rate and $\rho$ is a risk premium. The parameter $\eta$ controls the degree of flexibility of the nominal exchange rate and/or deviations from uncovered interest parity. ${ }^{8} \mathrm{We}$ also assume that the rate of crawl $\left(\Delta s_{t}{ }^{T}\right)$

\footnotetext{
${ }^{8}$ See Benes, Hurnik, and Vavra (2008) for alternative ways to model exchange rate dynamics in the context of managed exchange rate regimes.
} 
is such that in the long run the target exchange rate is determined by relative purchasing power parity adjusting for trends in the real exchange rate. This, in turn, implies that efforts by the central bank to manage the exchange rate have to be consistent with the inflation objective. ${ }^{9}$ This process is represented by Equation 12, where $\bar{\pi}$ stands for the domestic inflation target, $\overline{\pi^{*}}$ is the US inflation rate and $\Delta \bar{z}$ is the change in the equilibrium real exchange rate.

$$
\begin{gathered}
s_{t}=\eta_{1} s_{t}^{T}+\left(1-\eta_{1}\right)\left(s_{t+1}-\left(i_{t}-i_{t}^{*}-\rho_{t}\right) / 4\right)+\varepsilon_{t}^{s} \\
s_{t}^{T}=s_{t-1}^{T}+\Delta s_{t}^{T} / 4 \\
\Delta s_{t}^{T}=\sigma_{1} \Delta s_{t-1}^{T}+\left(1-\sigma_{1}\right)\left(\bar{\pi}_{t}-\bar{\pi}_{t}^{*}+\Delta \bar{z}_{t}\right)+\varepsilon_{t}^{\Delta s^{T}}
\end{gathered}
$$

The modification to the UIP condition is very general, but by allowing for a parameter $\left(\eta_{1}\right)$ to capture the degree of capital mobility and the response of the exchange rate to monetary policy the model is better able to fit of the data. It also permits us to better characterize the policy framework in place in Rwanda, typified by active exchange rate management through the use unconventional instruments (interventions, moral suasion, etc.) and where dual nominal anchors coexist. This setting can be used to characterize the policy frameworks of other frontier markets in the region. Other issues that arise from this adaptation, such as the relationship between international reserve stocks and the risk premium, or the two-instrument/two-target problem more generally are not incorporated. ${ }^{10}$

\section{iv. Interest Rate Policy Rule}

We close the model by introducing a monetary policy reaction function, according to which the central bank sets the interest rate in response to deviations of the one-year ahead inflation forecast from the inflation target and the output gap (Equation 13). ${ }^{11}$ Here $\bar{i}$ is the long run (neutral) nominal interest rate, $\pi 4$ is year on year (YoY) inflation rate, $\bar{r}$ is the neutral real interest rate and $\varepsilon^{i}$ is an error term that can be interpreted as a measure of the unsystematic component of monetary policy.

\footnotetext{
${ }^{9}$ Modifications to the central bank's exchange rate policy can be captured either through changes in parameter $\eta$, changes in $s_{t}^{T}$, or changes in the rate of crawl.

${ }^{10}$ See, for example, Benes, Berg, Portillo and Vavra (2013) and Ostry, Ghosh and Chamon (2012).

${ }^{11}$ We use the overnight interbank rate as a proxy for the stance of monetary policy in Rwanda. An increase of the interbank rate is interpreted as a tightening of monetary policy whereas a decrease reflects a loosening of policy. A follow-up paper will introduce formally the role of monetary aggregates in the conduct of policy.
} 


$$
\begin{gathered}
i_{t}=\tau_{1} i_{t-1}+\left(1-\tau_{1}\right)\left(\bar{i}_{t}+\tau_{2}\left(\pi 4{ }_{t+4}-\bar{\pi}_{t+4}\right)+\tau_{3} \operatorname{ygap}_{t}\right)+\varepsilon_{t}^{i} \\
\bar{i}_{t}=\bar{r}_{t}+\bar{\pi}_{t+4}
\end{gathered}
$$

We also specify a stochastic process for the inflation target (Equation 15), which allows us to simulate different disinflation paths.

$$
\bar{\pi}_{t}=\tau_{4} \bar{\pi}_{t-1}+\left(1-\tau_{4}\right) \pi^{s s}+\varepsilon_{t}^{\bar{\pi}}
$$

\section{v. Long Run Trends}

The long-run values of the real interest rate, the change in potential output and the real exchange rate are assumed to follow a simple first order autoregressive process given by:

$$
\begin{gathered}
\bar{r}_{t}=\psi_{1} \bar{r}_{t-1}+\left(1-\psi_{1}\right) \bar{r}_{s s}+\varepsilon_{t}^{\bar{r}} \\
\Delta \bar{y}_{t}=\psi_{2} \Delta \bar{y}_{t-1}+\left(1-\psi_{2}\right) \Delta y_{s s}+\varepsilon_{t}^{\Delta \bar{y}} \\
\Delta \bar{z}_{t}=\psi_{3} \Delta \bar{z}_{t-1}+\left(1-\psi_{3}\right) \Delta z_{s s}+\varepsilon_{t}^{\Delta \bar{z}}
\end{gathered}
$$

where $\Delta \bar{y}_{s s}, \Delta \bar{z}_{s s}$ and $\bar{r}_{s s}$ are the steady state values of potential output growth, the change in the real exchange rate and the real interest rate, respectively.

\section{vi. Foreign Block}

The dynamics of our model are completed by adding a simple rest of the world block, which we proxy with US variables. The block is comprised by a foreign output gap equation ( ygap *), an autoregressive process for the foreign neutral real interest rate $\left(\bar{r}^{*}\right)$ and headline inflation $\left(\pi^{*}\right)$, and an nominal interest rate policy rule $\left(i^{*}\right)$.

$$
\begin{gathered}
\operatorname{ygap}_{t}^{*}=a_{1} \operatorname{ygap}_{t-1}^{*}+\varepsilon_{t}^{y_{t} g a p^{*}} \\
\bar{r}_{t}^{*}=a_{2} \bar{r}_{t-1}^{*}+\left(1-a_{2}\right) \bar{r}_{s s}^{*}+\varepsilon_{t}^{\overline{r^{*}}} \\
i_{t}^{*}=a_{3} i_{t-1}^{*}+\left(1-a_{3}\right)\left(\bar{r}_{t-1}^{*}+\pi_{s S}^{*}+a_{4}\left(\pi_{t+4}^{4^{*}}-\pi_{s S}^{*}\right)\right)+\varepsilon_{t}^{i^{*}} \\
\pi_{t}^{*}=a_{5} \pi_{t-1}^{*}+\left(1-a_{5}\right) \pi_{s s}^{*}+\varepsilon_{t}^{\pi^{*}}
\end{gathered}
$$

\section{B. Data and Calibration}

The complete dataset along with the sources is described in Table 1. The database spans from 2003Q1 to 2013Q3. ${ }^{12}$ The disaggregation of inflation into core, food and oil follows the National

\footnotetext{
${ }^{12}$ Monthly series are averaged to quarterly frequencies.
} 
Institute of Statistics all-urban consumer price index. The weight for food and non-alcoholic beverages in the overall CPI basket is 35.4 percent, whereas the weight for oil (transport) is 11.9 percent. Core CPI is calculated by excluding food and oil CPI from the overall CPI index. The international oil and food price indexes are those of the World Economic Outlook (WEO). The GDP and CPI series are seasonally adjusted using the X12-ARIMA filter. The quarterly GDP data is also smoothened using the Hodrick-Prescott (HP) filter, using a smoothening parameter of 0.5 . This de-trending of the series seeks to remove some of the volatility associated to supply shocks, which are difficult to model in structural terms.

The model parameters are calibrated to match the broad properties of the data, following basic economic principles and how sensible the properties of the resulting model look (Table 2). ${ }^{13}$ The steady state values of the real interest rate, output growth and the real exchange rate change correspond to the average of the last 6 years. The inflation target is consistent with the target of the NBR of 5 percent. To check the consistency of our choice of parameters, we estimate the sacrifice ratio obtained from the model and match it with the sacrifice ratio calculated from the observed data for the disinflationary period of 2008Q2-2010Q3, following Ball (1994). The observed sacrifice ratio (amount of output that must be foregone to achieve a given permanent reduction in inflation) turns out to be 2.0 for headline inflation, while the model's sacrifice ratio stands at 1.8 .

Figures 1-3 present a set of the model impulse response plots that illustrate its basic properties. ${ }^{14}$ A positive aggregate demand shock $\left(\varepsilon^{y g a p}=1\right)$ translates into increases in core, food and oil inflation by 0.55 percent, 0.4 and 0.35 percent (all presented on a quarter on quarter basis) respectively. The central bank then responds by tightening monetary policy and increasing the interest rate. Inflation returns back to target as the exchange rate appreciates and a negative output gap opens up. Figures 2 , presents the responses to supply shocks to core ( $\varepsilon^{\text {core }}=1$ ), food $\left(\varepsilon^{\text {food }}=1\right)$ and oil $\left(\varepsilon^{\text {oil }}=1\right)$ inflation. In all three cases, the central bank responds by tightening policy, but less so in the case of shocks to food and oil inflation. Accordingly, in all cases tighter policy leads to a negative (even though small) output gap and an appreciation of the exchange rate.

\footnotetext{
${ }^{13}$ See Berg, Karam, Laxton (2006) and Andrle et al. (2013 a, b) for guidelines in calibrating this class of models in low income economies.

${ }^{14}$ In all cases, these correspond to responses to a temporary 1 percent increase during one-quarter in the shock term. The results are presented in deviations from steady-state values.
} 


\section{Box 1. An Estimate of the Sacrifice Ratio for Rwanda}

Ball (1994) develops a simple method for estimating the sacrifice ratio, defined as the ratio of the total output loss to the change in trend inflation, by identifying disinflation episodes and calculating the associated output losses. Disinflation episodes are defined as time periods that meet two criteria: (i) a period in which trend inflation, defined as a centered, nine-quarter moving average of observed headline inflation, starts at an inflation peak and ends at a through with an annual rate at least two points lower than the peak, and (ii) there is a significant tightening of monetary policy near the start of disinflation. These imply that declines in inflation arising from supply shocks are either too small or transitory to meet the disinflation criteria. Using quarterly data we identify one disinflation episode over the 2000-2011 period (2008Q2-2010Q3). This result is consistent with other methods that seek to identify monetary policy shocks in Rwanda (see, for example, Berg et al (2013).

An additional set of assumptions is used to define trend output: (i) output is at its trend/natural level at the start of a disinflation episode, (ii) output is back to its trend level four quarters after the end of an episode, and (iii) trend output grows log-linearly between the two points. These, in turn, imply that shifts in demand are the only source of changes in inflation. We also estimate two alternative values of trend output with variations of the Hodrick-Prescott filter. The final estimate of the sacrifice ratio (2) is a simple average of the sacrifice ratio using the three different estimates of trend output.

\section{Box Figure 1. Rwanda: Headline Inflation (Percent)}

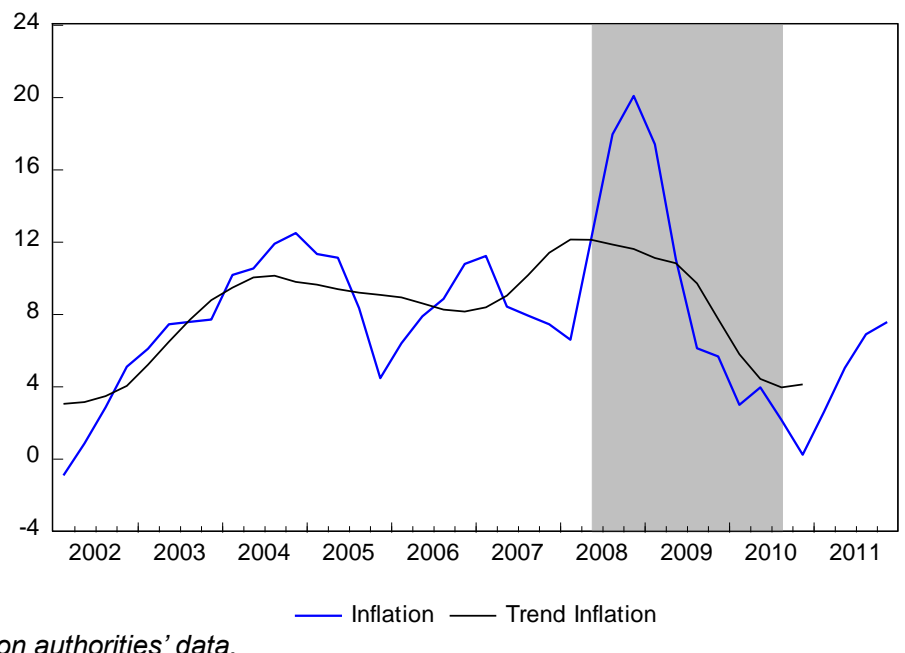

Sources: IMF staff based on authorities' data. 


\section{Filtering RWAndan Data through the Model}

Written in its state-space form, the model allows for the unobserved variables (state variables) to be estimated with the Kalman Filter. ${ }^{15}$ Figures 5-7 present the trend and gap components of the real exchange rate $\left(z_{t}\right)$, the real interest rate $\left(r r_{t}\right)$ and output $\left(y_{t}\right)$, respectively. The estimate of the output gap permits to identify a complete business cycle between $2008 \mathrm{H} 1$ and $2011 \mathrm{H} 1$, and a second one unfolding after $2011 \mathrm{H} 2$. The model captures well the negative effects of the global financial crisis on output, and the subsequent expansion on the back of more accommodative policies, as indicated by a negative real interest rate gap. The negative effect of the 2012 aid shock on economic activity is also evident, with the opening up of a negative output gap (of about 2 percent of GDP in 2013). The real depreciation triggered by this episode and the consequent tightening of monetary policy (as signaled by higher real interest rates) is also well captured by the model. ${ }^{16}$

The model also allows us to decompose the observed data into the different structural shocks hitting the economy. The results (Figures 8-11) indicate that exchange rate shocks play an important role in inflation dynamics all throughout the period under consideration. Likewise, supply shocks in the food sector (and less so in the oil sector) seem to play a relevant role, whereas shocks to the exchange rate seem to have a more muted effect. Core inflation dynamics, on the other hand, seem to be dominated by exchange rate shocks, monetary policy shocks and demand shocks. The systematic nature of monetary policy shocks in the determination of core inflation, particularly since 2010 could either indicate that there is an additional element to include in the model's monetary policy rule (such as the role played by monetary aggregates), or that there are in fact areas of improvement on the way monetary policy is currently conducted to better anchor inflation expectations. ${ }^{17}$

\section{A. Forecast}

One way of assessing the reliability of the model is by evaluating its in-sample forecasting capabilities. We also present an out-of-sample forecast to showcase the usefulness of the tool to conduct policy analysis in a forward looking context.

\footnotetext{
${ }^{15}$ In our case, the set of unobserved states includes the gap (deviations from trend) components. The filtering exercise covers the period from 2008 onwards.

${ }^{16}$ The higher real depreciation after the aid shock was achieved through an upward adjustment in the rate of crawl by the central bank.

${ }^{17}$ Particularly when considering that monetary policy shocks seem to be negatively correlated with exchange rate shocks.
} 


\section{In-sample Forecast}

In-sample forecasts are generated on a quarterly basis, for the period 2007Q4- 2013Q4. We assume an equilibrium real exchange rate appreciation of 1 percent, with inflation converging to a target of 5 percent. For this exercise, the in-sample variables of the rest of the world block and the world oil and food prices are exogenous and equal to their observed values (the trajectories of the external variables and world food and oil prices are shown in Figure 12).

The forecasts are shown in Figure 13. The model predicts the disinflation of 2009 fairly well, however, it underestimates the magnitude of the inflationary pressures in 2010. In part, this could be driven by the fact that food and oil prices dropped sharply in 2009, and a carry through of such a magnitude of 2010 could not be plausibly expected. The model does tend to closely track inflation in 2011 and after 2012, also helped by the fact that inflation was less volatile than in the previous years. All in all, the results suggest that the model is broadly satisfactory, particularly at short horizons. However, its performance is somewhat less reliable in the presence of large exogenous shocks, as in 2008. Nevertheless, a comparison of the in-sample model forecasts with those of a simple random walk model shows that the model outperforms the random walk model, especially at longer horizons (Table 3 ).

\section{Out-of-sample Forecast}

The main outputs of the out-of-sample forecast, starting from 2014Q1 are presented in Figure 15. This is in a context where the aid situation has normalized with the return of donors, but near term growth has slowed down, with 2014 growth projected at 6 percent, while we estimate potential GDP growth to stand at 7 percent. The economy is thus operating below its potential, and the negative output gap ( 2 percent of GDP at the start of the simulation) is not expected to close until the first half of 2015. The exchange rate pressures noticed at the peak of the aid shock have subsided significantly. The Rwanda Franc depreciated by nearly 12 percent between January 2012 and December 2013, but the pace of depreciation has slowed in the first quarter of 2014,

reflecting both the slowdown in economic activity and resulting decline in demand for imports as well as a return of donor flows. On the external front, the main change we anticipate over the forecast horizon is a normalization of US interest rates as after 2015. Commodity prices are expected to remain relatively stable over the period.

Bearing in mind these conditions, the baseline forecast suggests that headline inflation will remain within a range of 3 to 5 percent in 2014, and the NBR's current monetary policy stance can be considered as appropriate. However, should growth weaken further there may be room to ease monetary conditions to spur economic activity.

\section{Conclusions}

The NBR has recently had significant success in containing inflationary pressures and it is accelerating its efforts to enhance its policy analysis apparatus. Such initiatives aim to overcome 
previous concerns regarding the lack of timely information and leading indicators. Such constraints hindered the NBR's response to economic developments, resulting in the policy stance being out of line with inflationary pressures. An FPAS, like the one presented here, provides a framework within which to analyze monetary policy in a systematic and forward-looking way. It can also improve the decision making processes by allowing the NBR to better gauge the response of the economy to policy changes and thus translate into superior policy and macroeconomic outcomes. The model allows us to show the key contributors to inflation in Rwanda, placing special emphasis on tracing the effects of food and oil price developments, as well as the nature of the exchange rate regime. These have been the main drives of the inflation dynamics in Rwanda during the period under consideration. In a context of incomplete information, the FPAS also allows us to draw inferences as regard the monetary policy stance and better understand the transmission mechanism. 
Table 1: Data Series

\begin{tabular}{ccc}
\hline Variable & Description & Source \\
\hline$s$ & Exchange rate (Franc/USD) & NBR \\
$y$ & Interbank rate & NBR \\
$C P I$ & Quarterly GDP & IMF IFS \\
$C P I^{\text {oil }}$ & Quarterly CPI (headline) & NISR \\
$C P I^{\text {food }}$ & Quarterly CPI (oil) & NISR \\
$\Delta P_{\text {oil }}^{\text {world }}$ & Quarterly CPI (food) & NISR \\
$\Delta P_{\text {food }}^{\text {world }}$ & International oil prices & IMF (WEO) \\
$C P I^{*}$ & International food prices index & IMF (WEO) \\
$i^{*}$ & US CPI & IMF (IFS/WEO) \\
$y g$ gap & US Federal Funds rate & IMF (IFS/WEO)
\end{tabular}

Note: compilation of quarterly GDP: For 2006 and afterwards, the IMF's annual GDP series is converted to a quarterly frequency using the authorities' quarterly GDP estimates. For the earlier period, quarterly weights computed from the authorities' quarterly GDP estimates for 2006-11 are applied to the IMF's annual series.

NISR: National Institute of Statistics for Rwanda

NBR: National Bank of Rwanda

WEO: World Economic Outlook

$I M F$ : International Monetary Fund

IFS: International Financial Statistics 
Table 2: Calibration

\begin{tabular}{|c|c|c|}
\hline Parameter & Description & Value \\
\hline & Output Gap Equation & \\
\hline$\beta_{1}$ & AR(1) parameter & 0.69 \\
\hline$\beta_{2}$ & Coefficient on real monetary conditions $(r m c i)$ & 0.47 \\
\hline$\beta_{3}$ & Coefficient on the foreign output gap & 0.05 \\
\hline \multirow[t]{2}{*}{$\beta_{4}$} & Weight of the real exchange rate gap in $r m c i$ & 0.30 \\
\hline & Core Inflation Equation & \\
\hline$\lambda_{1}$ & $\mathrm{AR}(1)$ parameter & 0.65 \\
\hline$\lambda_{2}$ & Coefficient on real marginal costs $(r m c)$ & 0.51 \\
\hline$\theta$ & Weight of the real exchange rate gap in $r m c$ & 0.20 \\
\hline \multirow[t]{2}{*}{$\alpha$} & $\mathrm{AR}(1)$ in inflation expectations process & 0.50 \\
\hline & Food Inflation Equation & \\
\hline$\lambda_{3}$ & AR(1) parameter & 0.35 \\
\hline$\lambda_{4}$ & Coefficient on international food price pressures & 0.17 \\
\hline \multirow[t]{2}{*}{$\lambda_{5}$} & Coefficient on the output gap & 0.06 \\
\hline & Oil Inflation Equation & \\
\hline$\lambda_{6}$ & $\mathrm{AR}(1)$ parameter & 0.35 \\
\hline \multirow[t]{2}{*}{$\lambda_{7}$} & Coefficient on inflation expectations & 0.57 \\
\hline & Headline Inflation & \\
\hline$w_{1}$ & Core inflation weight & 0.53 \\
\hline \multirow[t]{2}{*}{$w_{2}$} & Food inflation weight & 0.36 \\
\hline & Exchange Rate Rule & \\
\hline$\eta 1$ & Coefficient on the target exchange rate & 0.95 \\
\hline \multirow[t]{2}{*}{$\sigma_{l}$} & $\mathrm{AR}(1)$ parameter & 0.80 \\
\hline & Monetary Policy Rule & \\
\hline$\tau_{1}$ & Smoothing parameter & 0.45 \\
\hline$\tau_{2}$ & Coefficient on inflation forecast deviation from target & 2.10 \\
\hline$\tau_{3}$ & Coefficient on the output gap & 0.90 \\
\hline \multirow[t]{2}{*}{$\tau_{4}$} & $\mathrm{AR}(1)$ parameter in the inflation target process & 0.50 \\
\hline & Trends & \\
\hline$\psi_{1}$ & Persistence, long run real interest rate & 0.45 \\
\hline$\psi_{2}$ & Persistence, long run output growth & 0.38 \\
\hline \multirow[t]{2}{*}{$\psi_{3}$} & Persistence, long run real exchange rate & 0.55 \\
\hline & Foreign Block & \\
\hline al & Persistence in output gap & 0.80 \\
\hline$a 2$ & Persistence, real interest rate trend & 0.50 \\
\hline$a 3$ & Smoothening parameter in US Taylor rule & 0.80 \\
\hline a4 & Coefficient on expected inflation deviation from target & 3.50 \\
\hline \multirow[t]{2}{*}{ a5 } & $\mathrm{AR}(1)$ parameter & 0.30 \\
\hline & Steady state/long-run values & \\
\hline
\end{tabular}




\begin{tabular}{|c|c|c|}
\hline $\bar{r}_{s s}$ & Long run real interest rate & 3.50 \\
\hline$\Delta \bar{y}_{s s}$ & Long run output growth rate & 7.50 \\
\hline$\Delta \bar{z}_{s s}$ & Long run real exchange rate change & -1.00 \\
\hline $\bar{\pi}$ & Inflation target & 5.00 \\
\hline $\bar{r}_{s s}^{*}$ & Foreign long run real interest rate & 0.50 \\
\hline $\bar{\pi}^{*}$ & Foreign inflation target & 2.00 \\
\hline & Standard deviation of shocks & \\
\hline$\varepsilon^{y g a p}$ & Output gap shock & 0.15 \\
\hline$\varepsilon^{\text {core }}$ & Core inflation shock & 0.50 \\
\hline$\varepsilon^{\text {food }}$ & Food inflation shock & 1.50 \\
\hline$\varepsilon^{o i l}$ & Oil inflation shock & 1.50 \\
\hline$\varepsilon^{i}$ & Monetary policy rule shock & 0.60 \\
\hline$\varepsilon^{\bar{\pi}}$ & Inflation target shock & 3.20 \\
\hline$\varepsilon^{s}$ & Uncovered interest rate parity shock & 0.60 \\
\hline$\varepsilon^{\Delta s^{T}}$ & Exchange rate target shock & 1.50 \\
\hline$\varepsilon^{\bar{r}}$ & Long run real interest rate shock & 0.20 \\
\hline$\varepsilon^{\Delta \bar{y}}$ & Long run output growth shock & 0.27 \\
\hline$\varepsilon^{\Delta \bar{z}}$ & Long run real exchange rate shock & 0.36 \\
\hline$\varepsilon^{y g a p^{*}}$ & Foreign output gap shock & 0.25 \\
\hline$\varepsilon^{\bar{r}^{*}}$ & Foreign long run real interest rate shock & 0.75 \\
\hline$\varepsilon^{i^{*}}$ & Foreign interest rate shock & 0.45 \\
\hline$\varepsilon^{\pi^{*}}$ & Foreign inflation shock & 1.30 \\
\hline$\varepsilon^{\text {woil }}$ & World oil prices shock & 1.50 \\
\hline$\varepsilon^{w f o o d}$ & World food prices shock & 1.50 \\
\hline
\end{tabular}


Table 3: Goodness of fit

RMSE comparison to RW

\begin{tabular}{|c|c|c|c|c|c|c|c|c|}
\hline & $\stackrel{\sigma}{=}$ & ก & $\stackrel{s}{\circ}$ & q & $\sqrt[5]{5}$ & $\overline{8}$ & $\sigma$ & $\mathscr{8}$ \\
\hline Exchange rate level & 0.96 & 0.67 & 0.62 & 0.60 & 0.61 & 0.66 & 0.71 & 0.76 \\
\hline Headline Inflation (YoY) & 0.46 & 0.45 & 0.42 & 0.44 & 0.36 & 0.28 & 0.17 & 0.29 \\
\hline GDP growth (YoY) & 0.80 & 0.45 & 0.51 & 0.57 & 0.71 & 0.52 & 0.54 & 0.66 \\
\hline Interbank Rate & 1.37 & 0.94 & 0.77 & 0.72 & 1.06 & 1.23 & 1.37 & 1.25 \\
\hline Real Interest Rate & 0.67 & 0.65 & 0.71 & 0.58 & 0.63 & 0.70 & 0.72 & 0.68 \\
\hline Food Inflation (YoY) & 0.56 & 0.55 & 0.53 & 0.58 & 0.55 & 0.49 & 0.41 & 0.35 \\
\hline Oil Inflation (YoY) & 0.49 & 0.52 & 0.56 & 0.58 & 0.60 & 0.61 & 0.56 & 0.46 \\
\hline Core Inflation (YoY) & 0.90 & 0.87 & 0.85 & 0.76 & 1.39 & 0.97 & 0.73 & 0.95 \\
\hline
\end{tabular}


Figure 2: Impulse Response Functions I (Demand Shock)
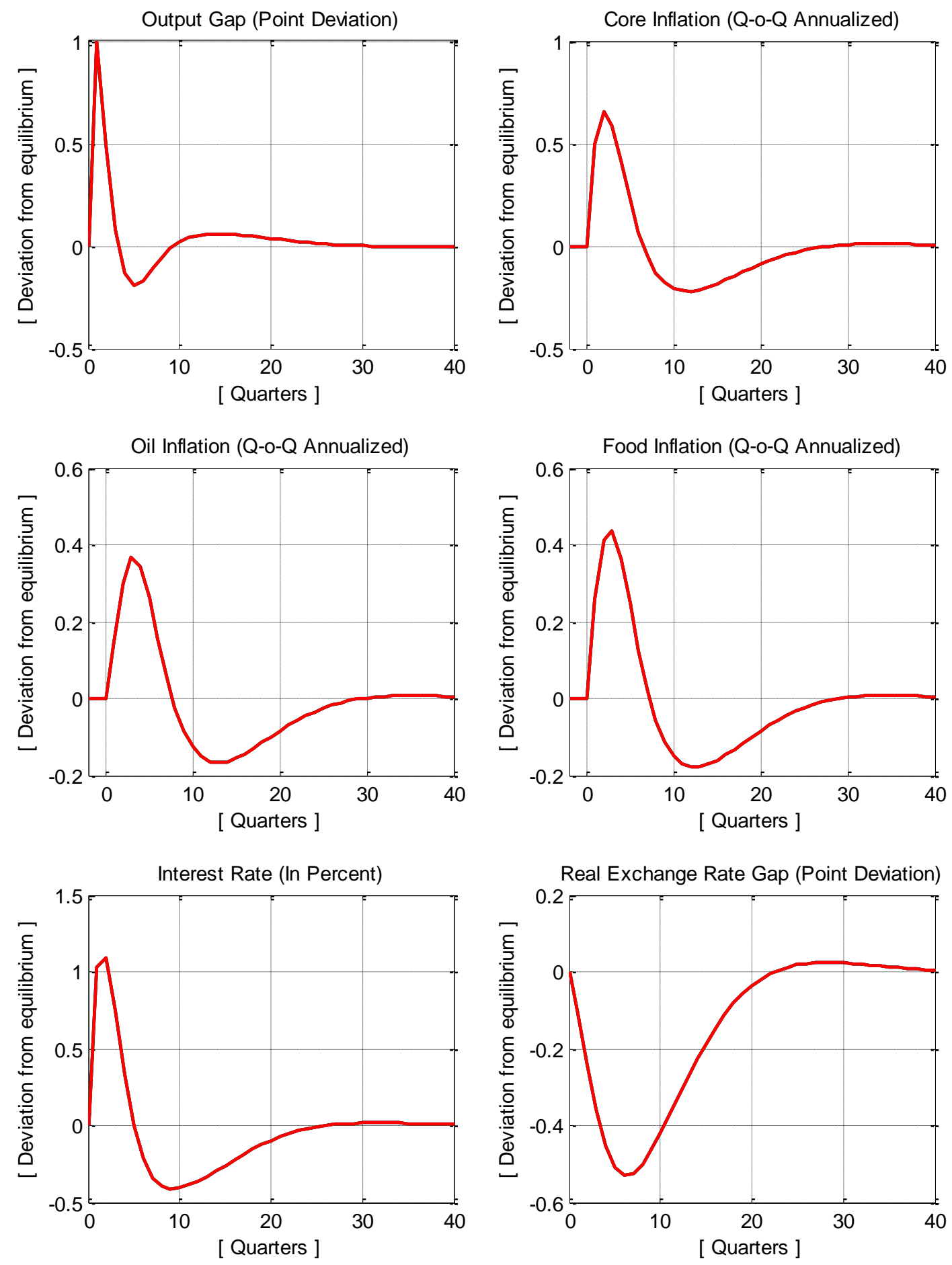
Figure 3: Impulse Response Functions II (Supply Shocks: Core, Food, Oil Inflation)
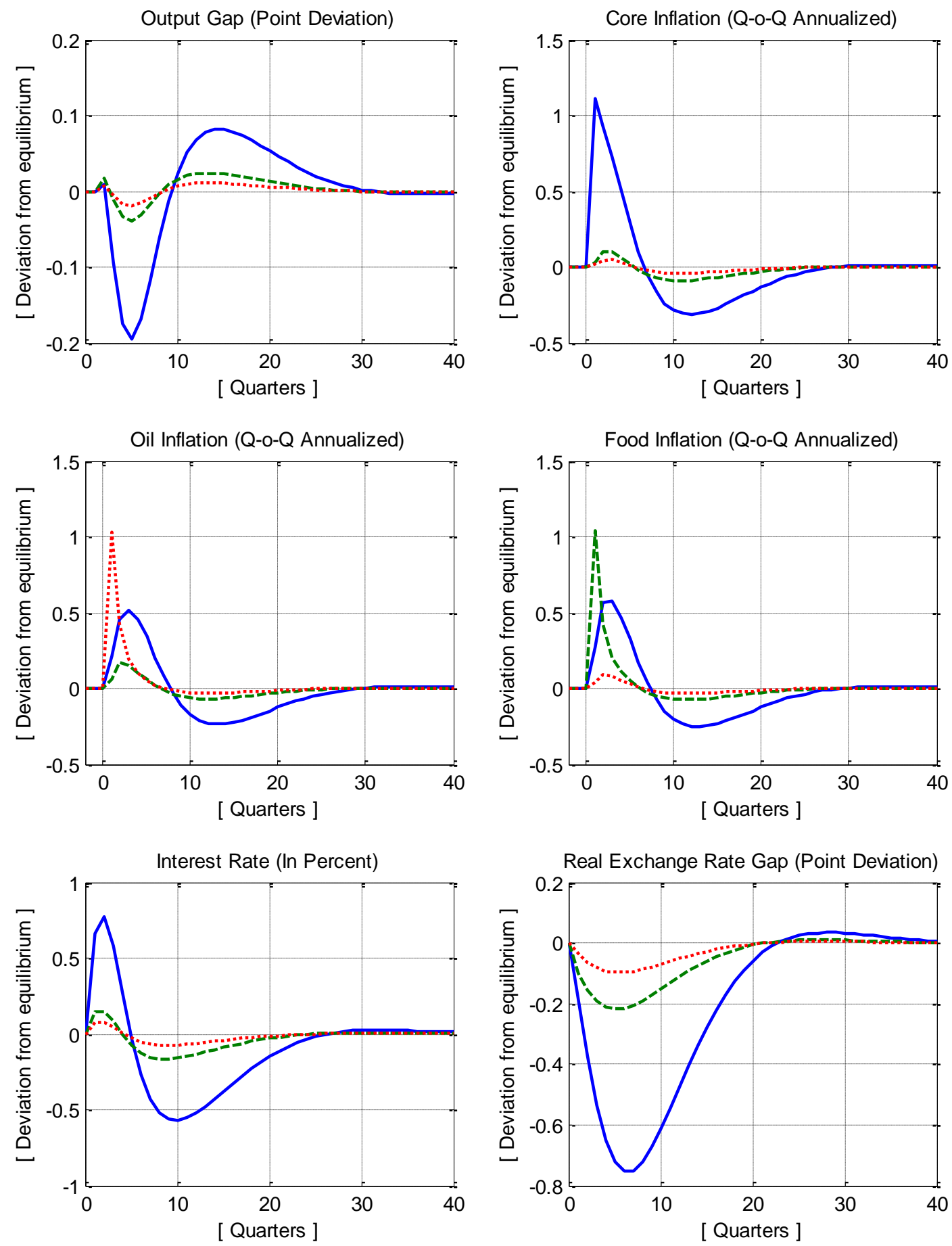

Core Inflation Shock - -.-- Food Inflation Shock '.......... Oil Inflation Shock 
Figure 4: Impulse Response Functions III (Interest Rate Shock)
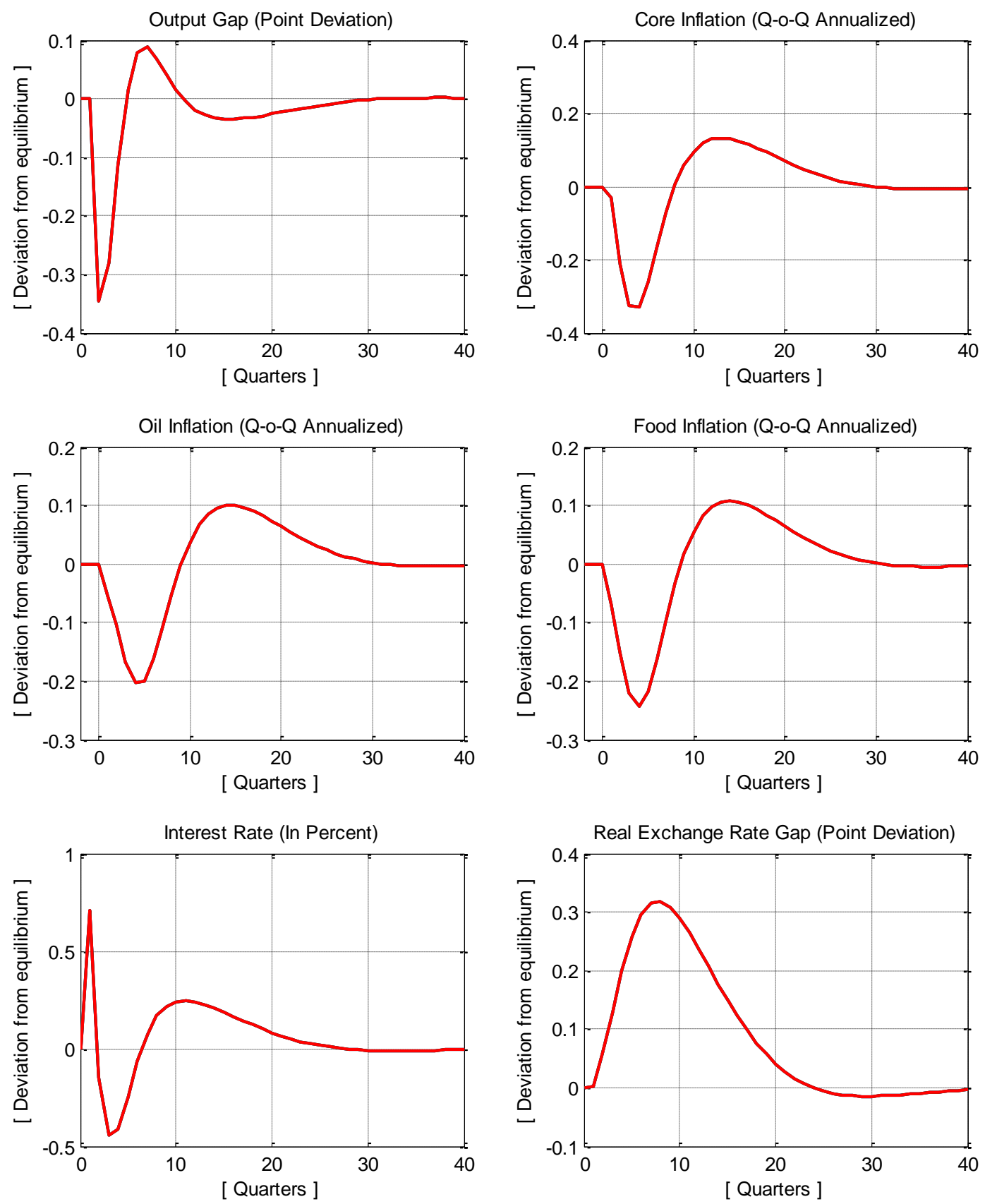
Figure 5: Real Exchange Rate Trend and Gap
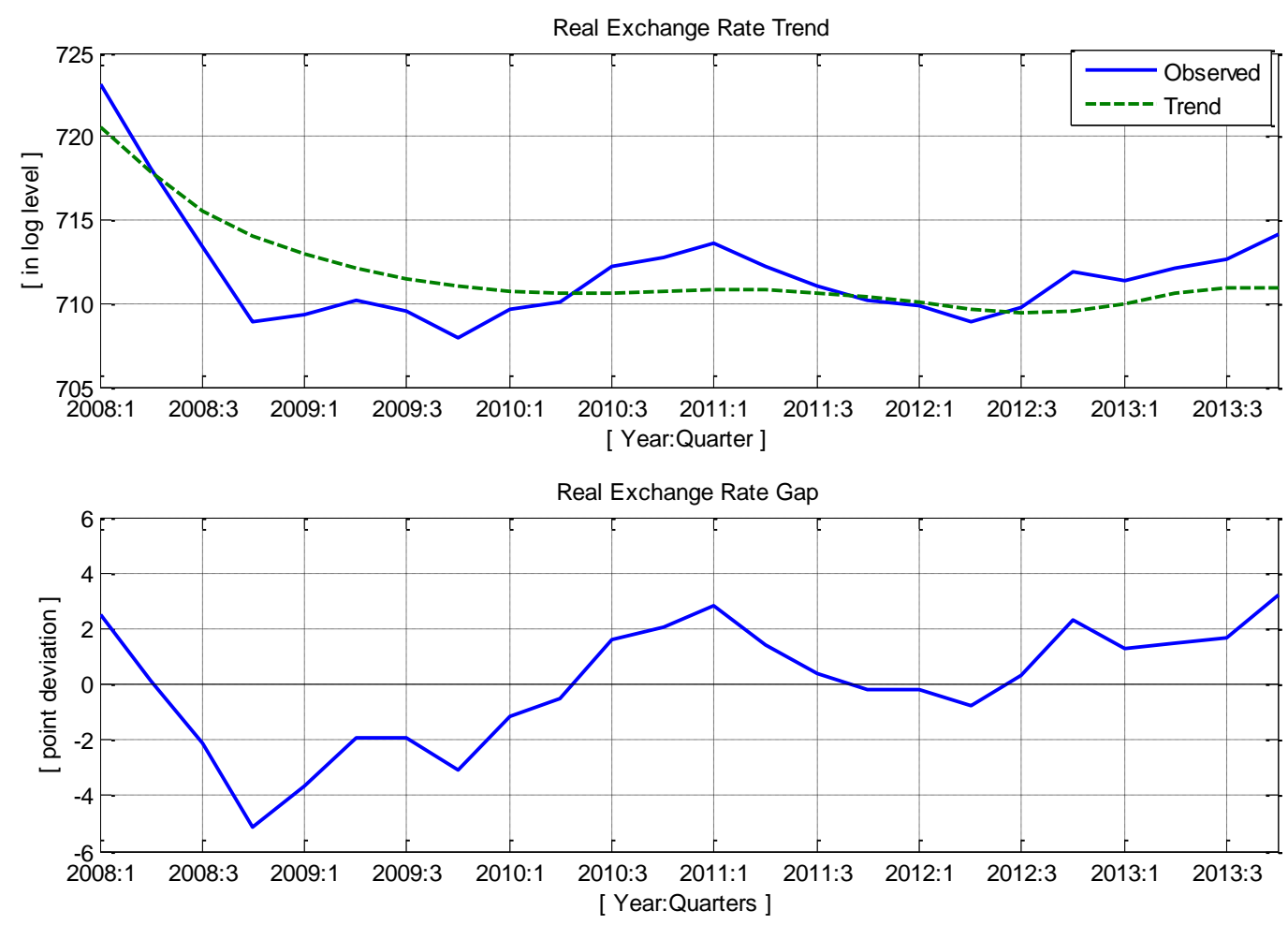
Figure 6: Real Interest Rate Trend and Gap
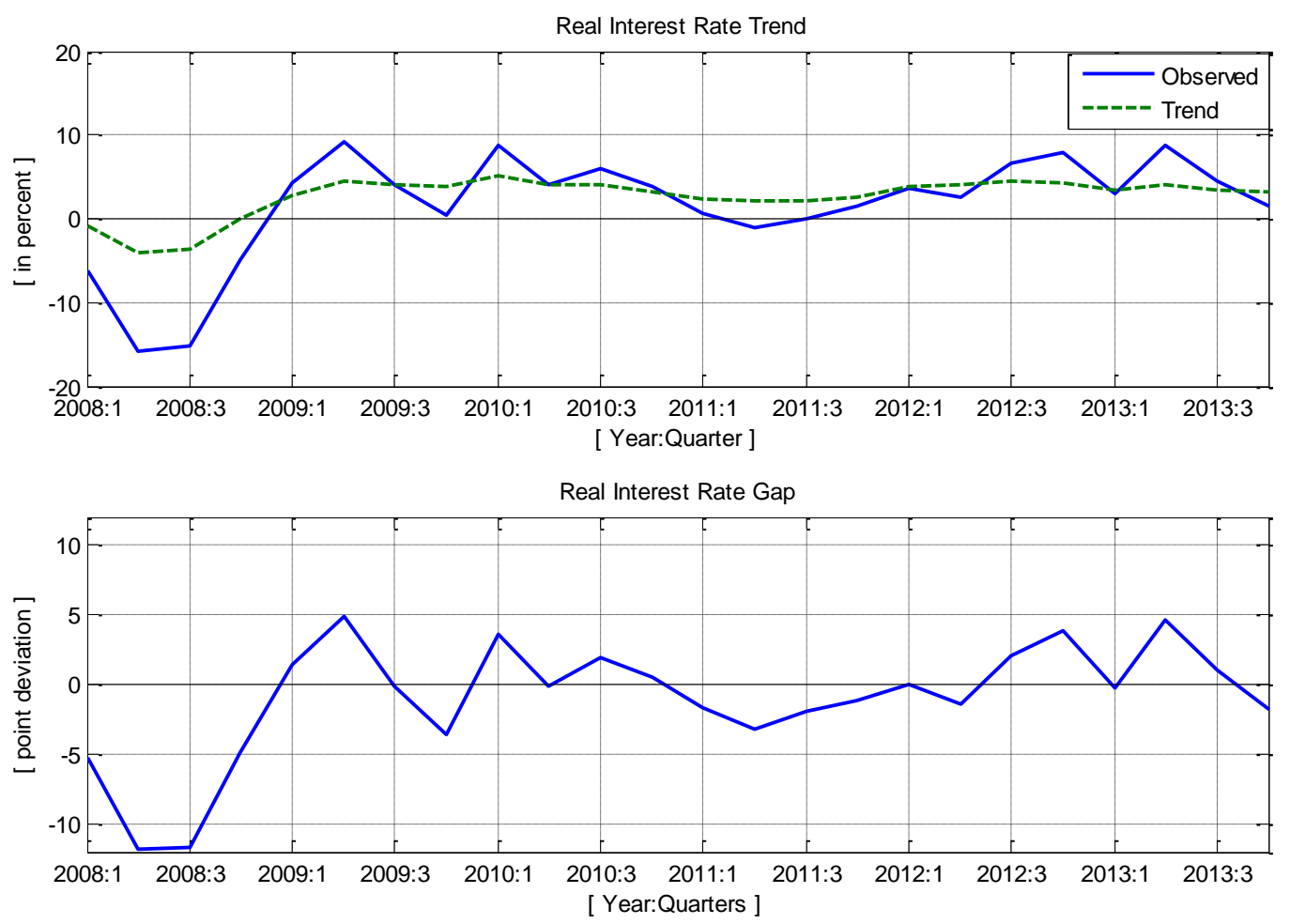
Figure 7: Output Trend and Gap
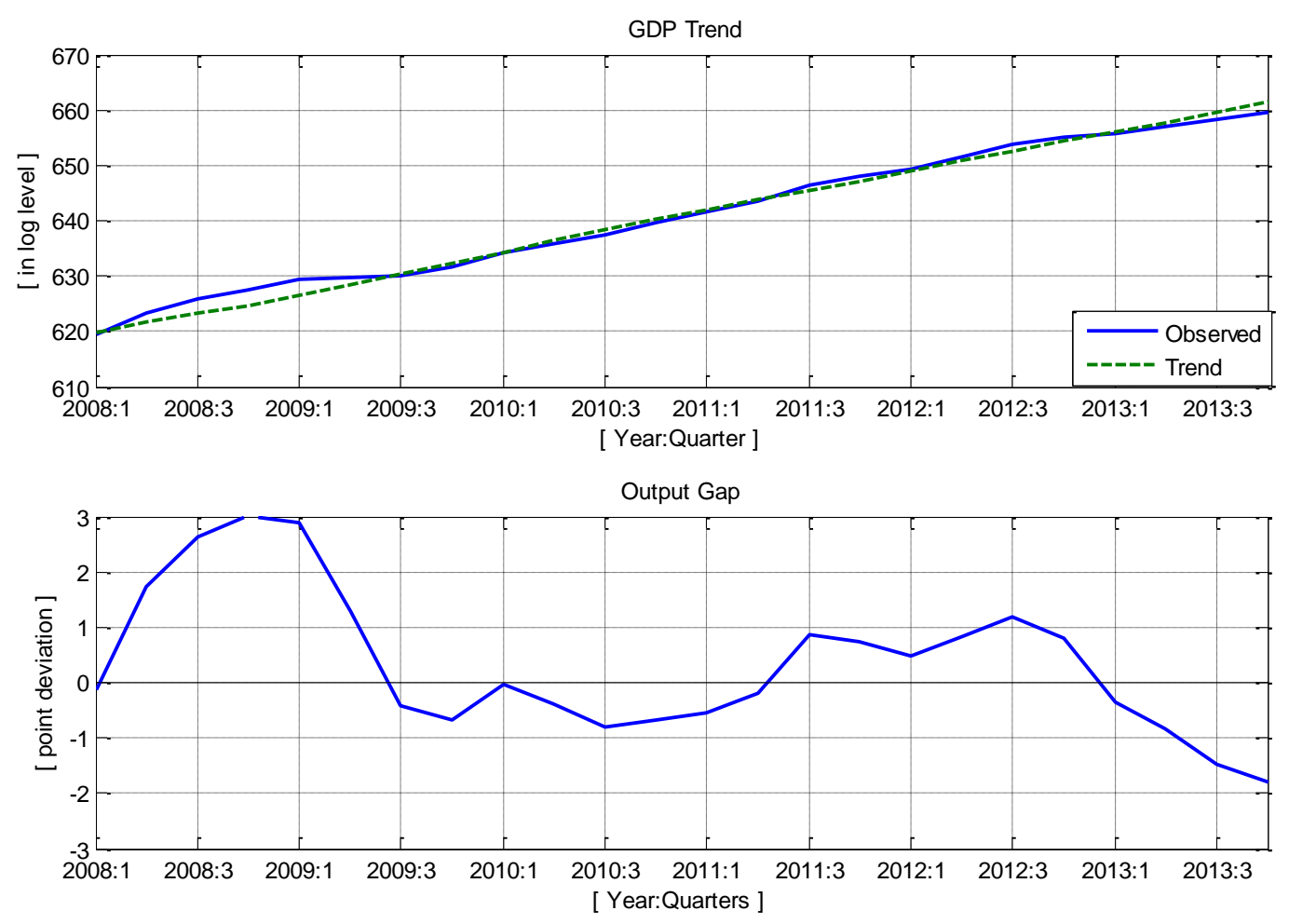
Figure 8: Shock Decomposition of Headline Inflation (YoY)

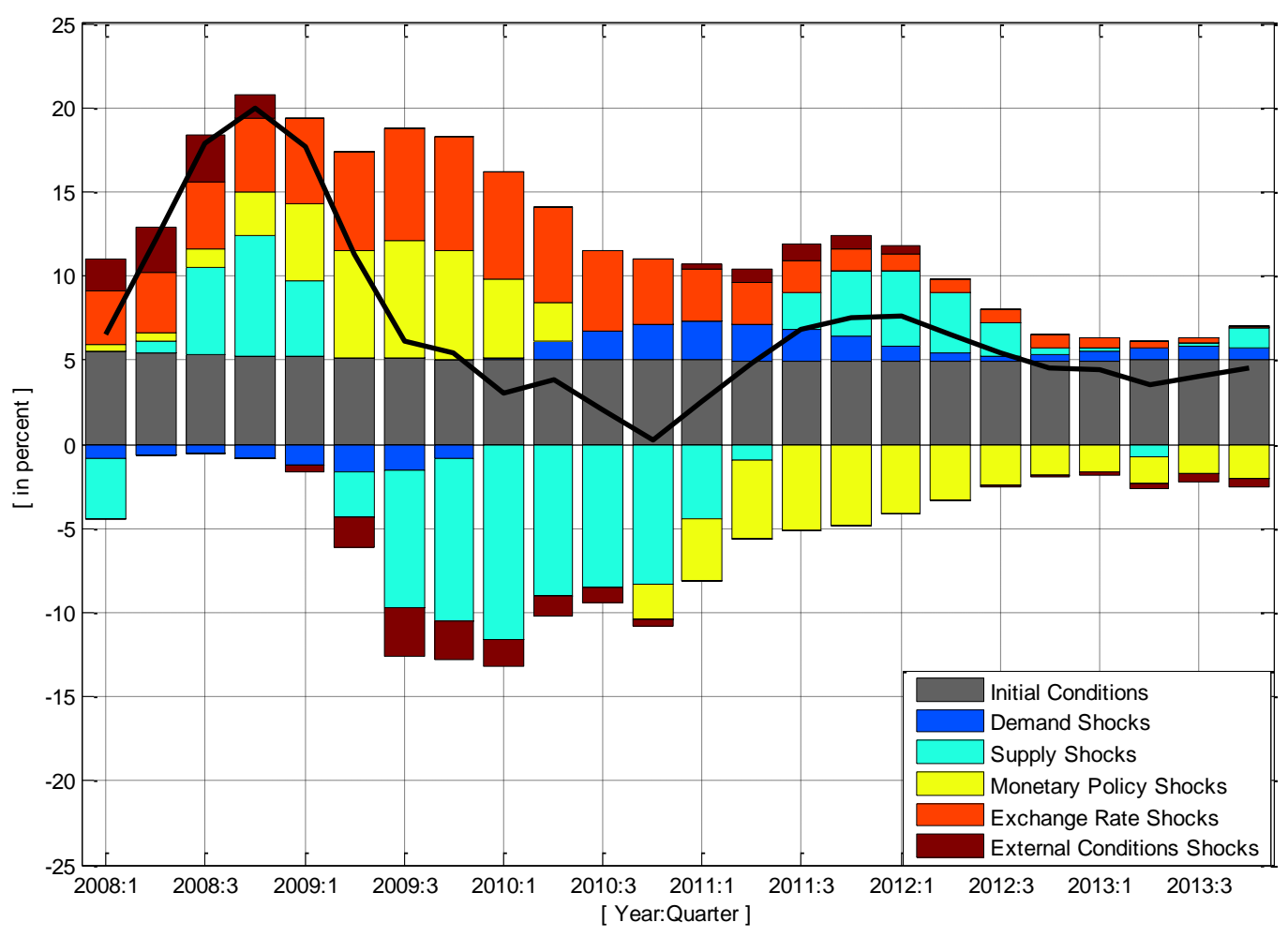


Figure 9: Shock Decomposition of Core Inflation (YoY)

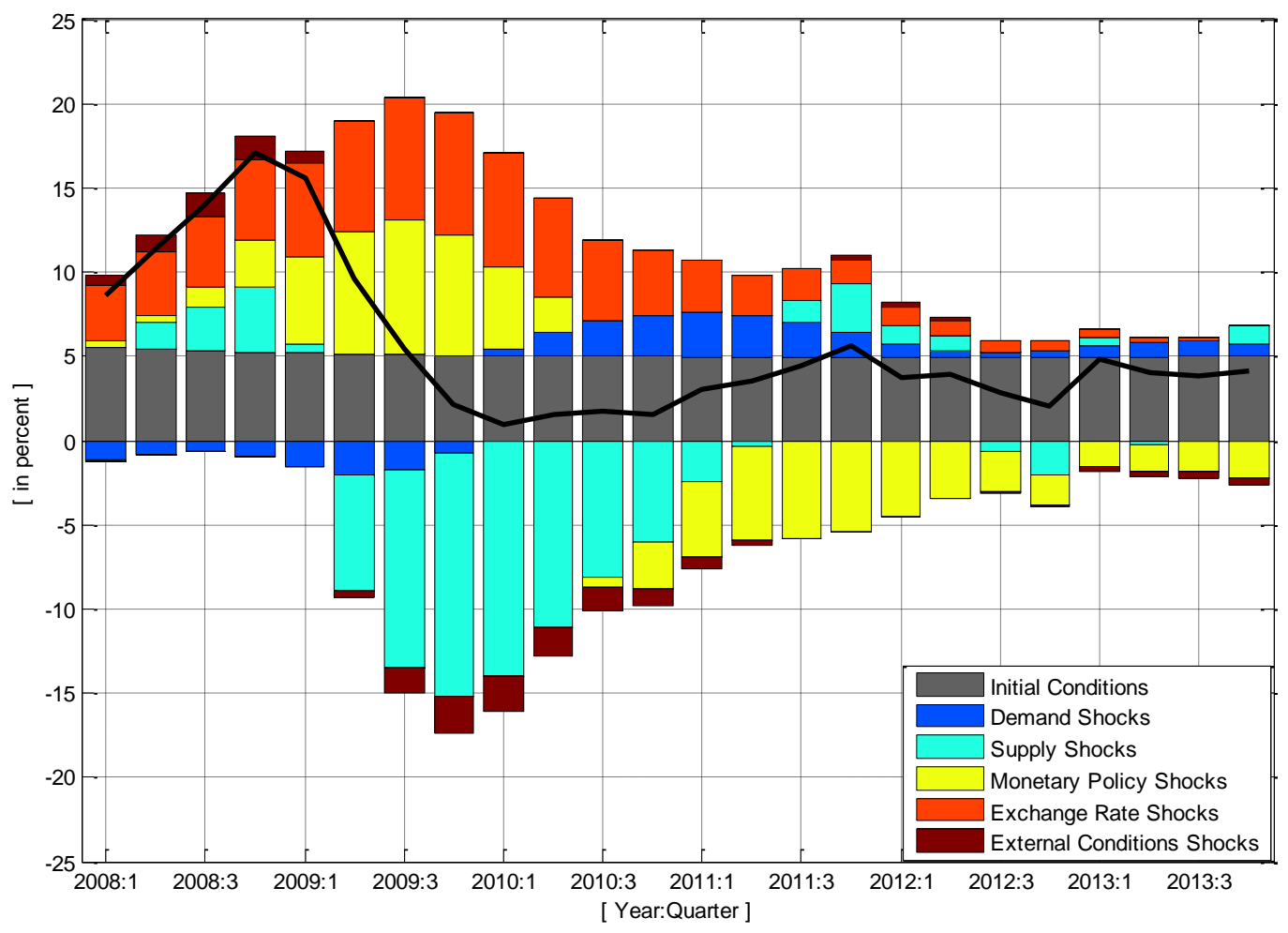


Figure 10: Shock Decomposition of Food Inflation (YoY)

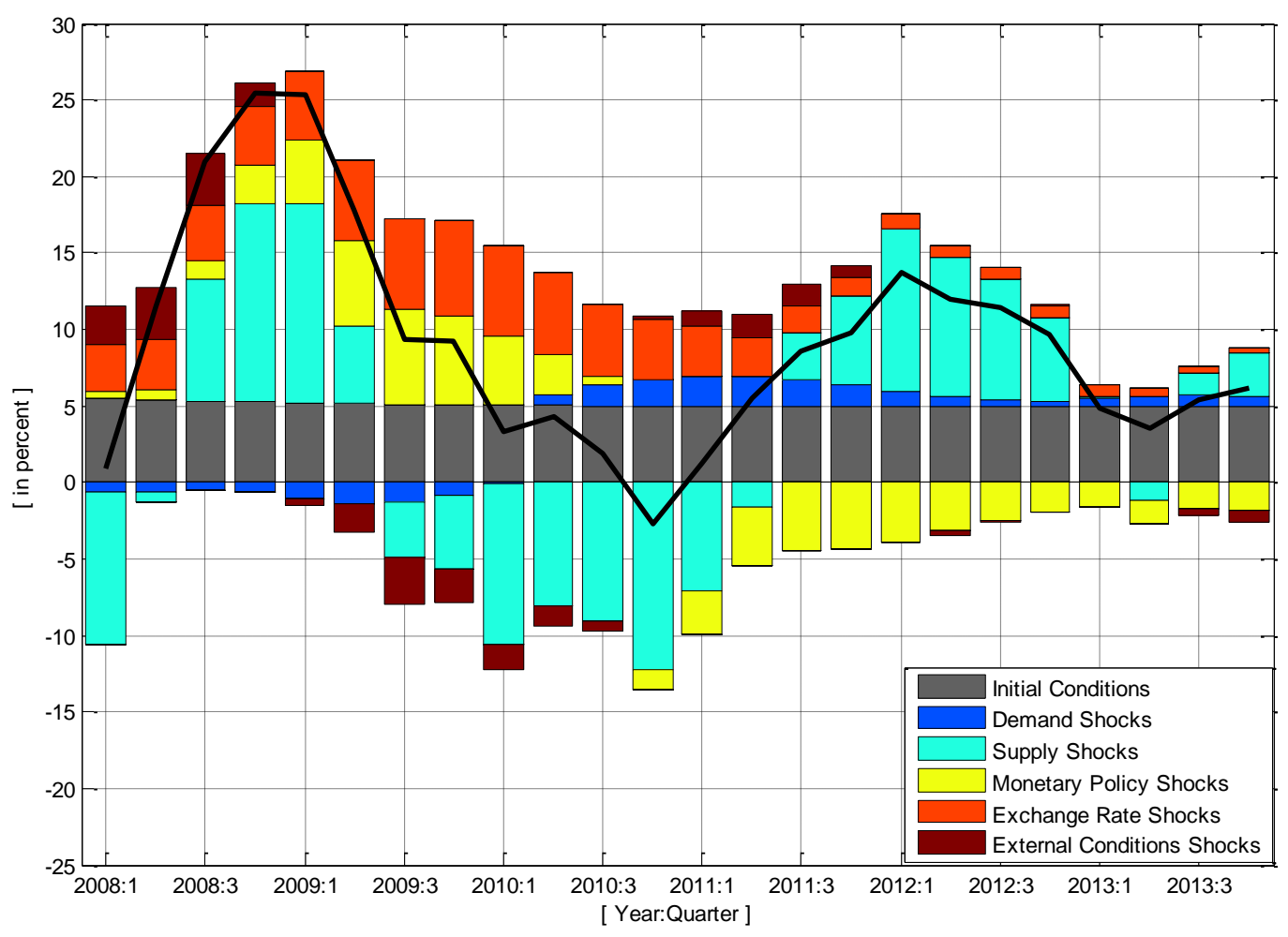


Figure 11: Shock Decomposition of Oil Inflation (YoY)

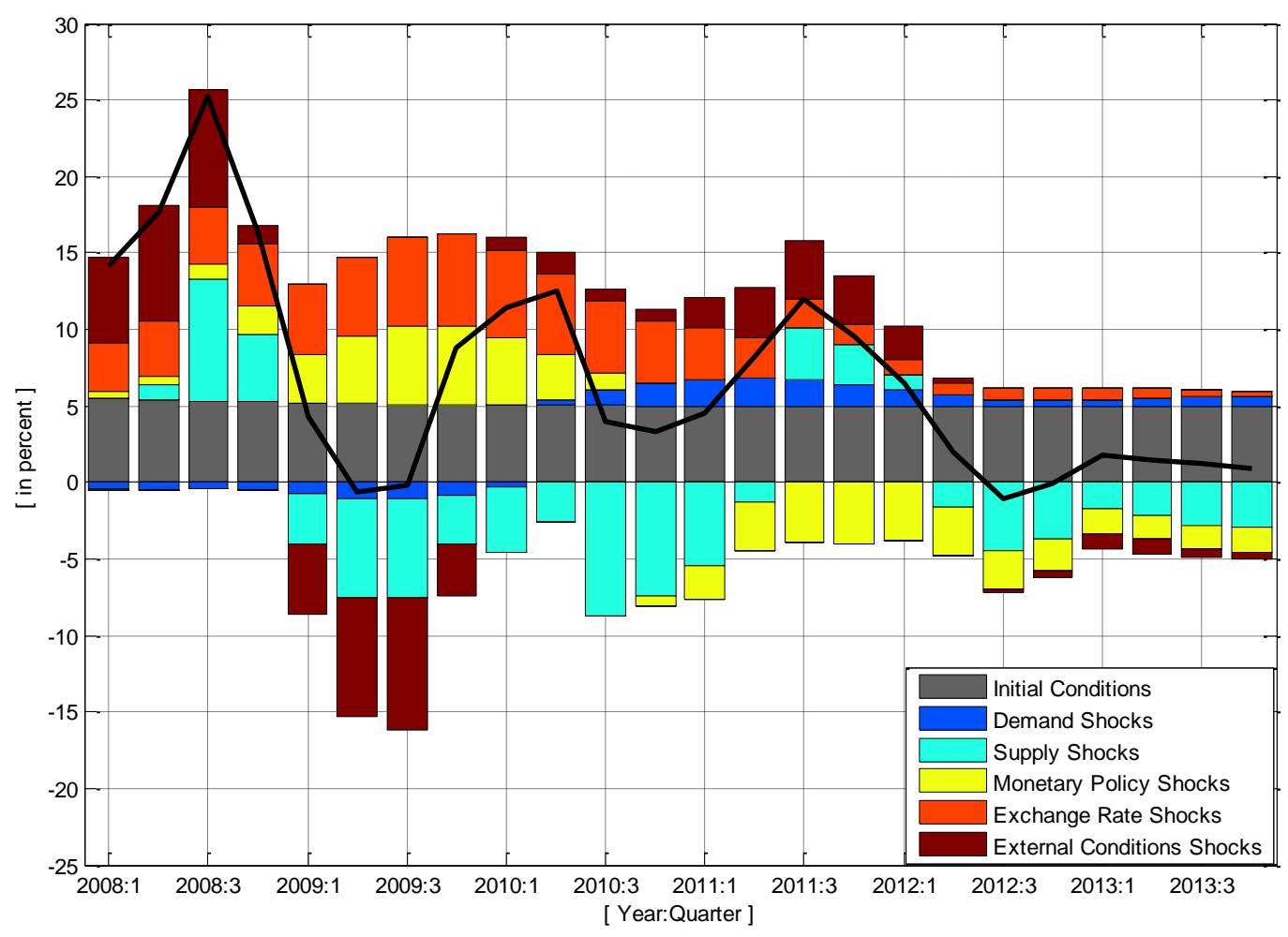


Figure 12: Shock Decomposition of the Output Gap

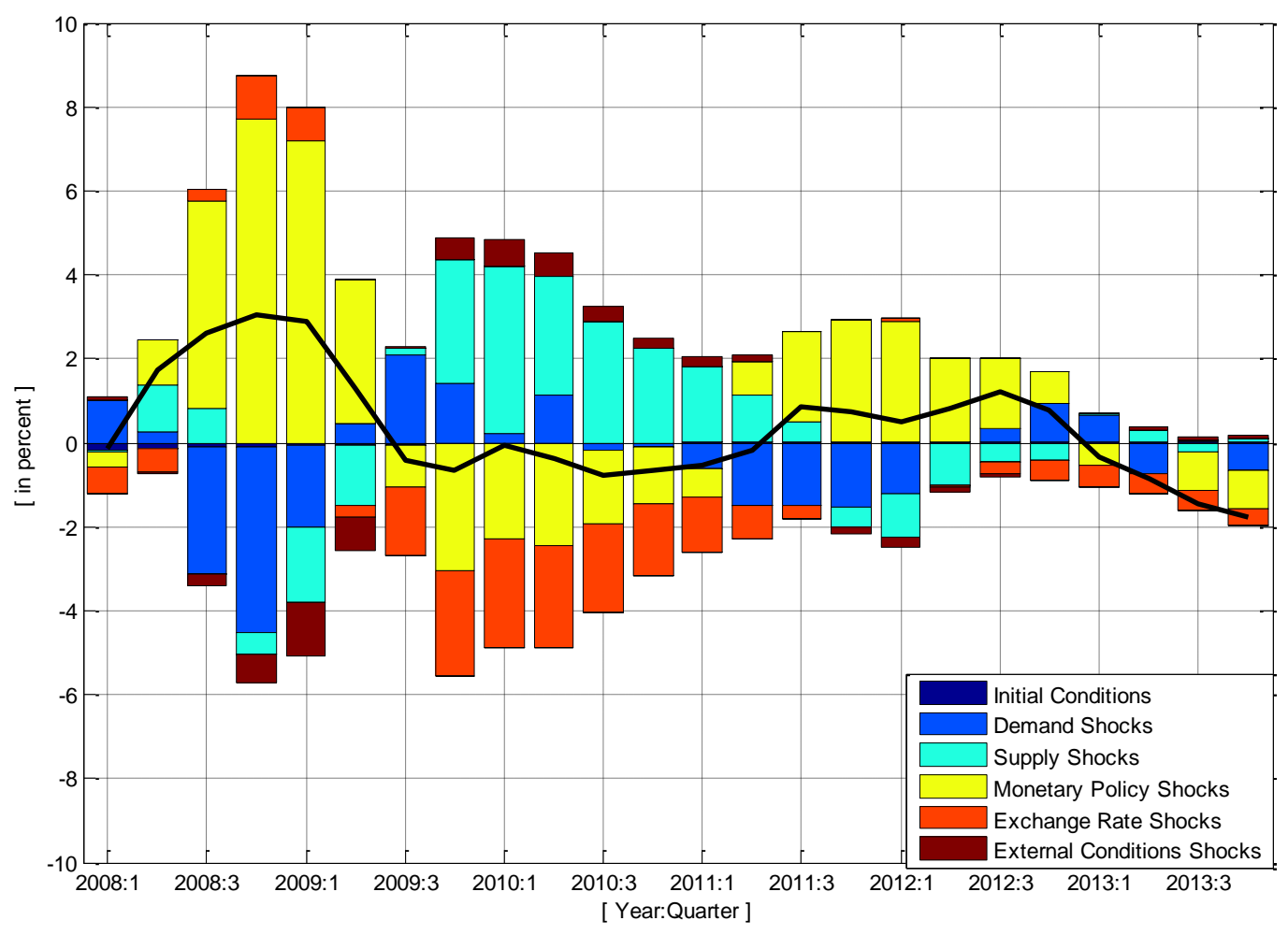


Figure 13: Exogenous Variables
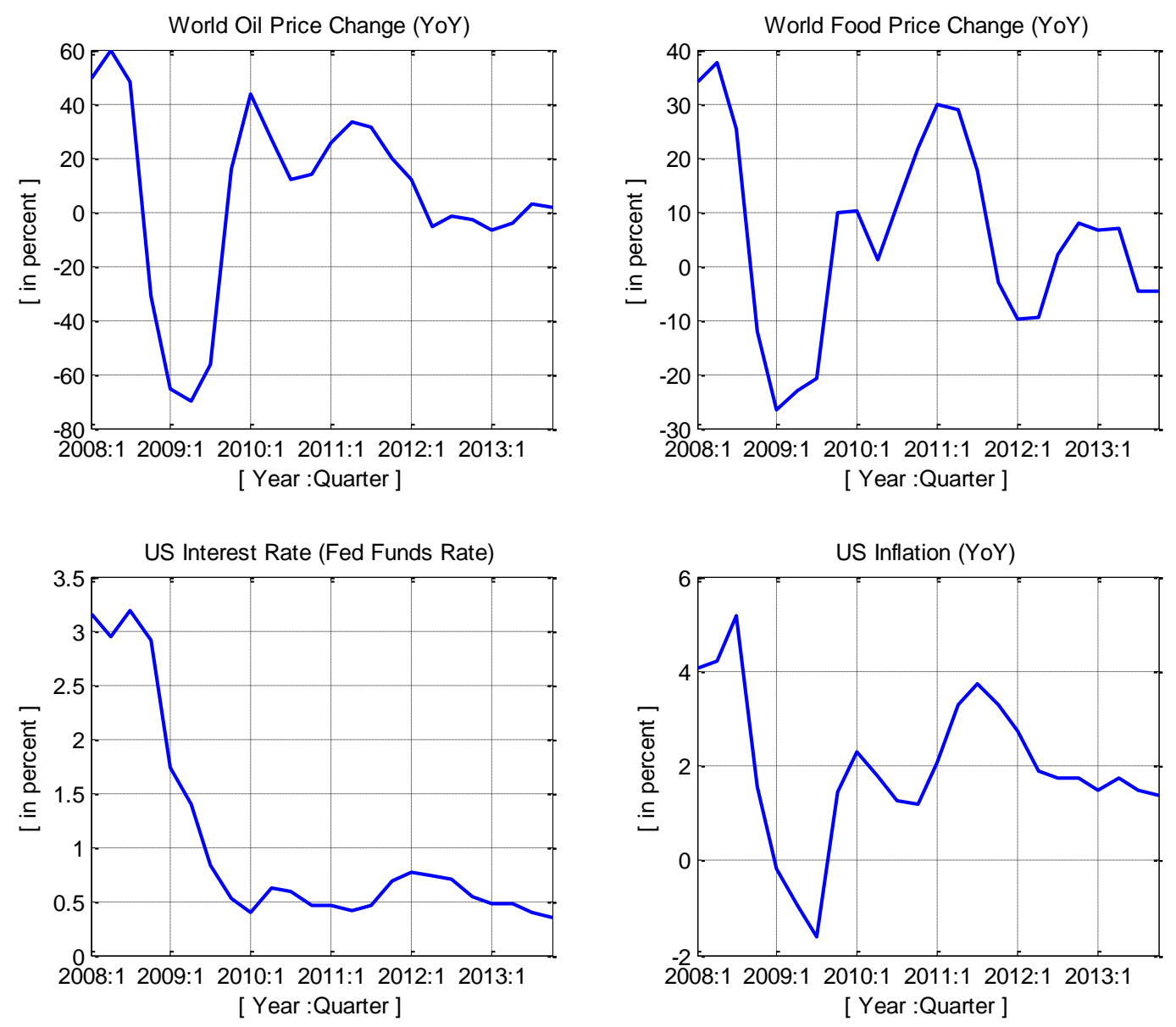
Figure 14: In-sample Forecast of the Main Variables
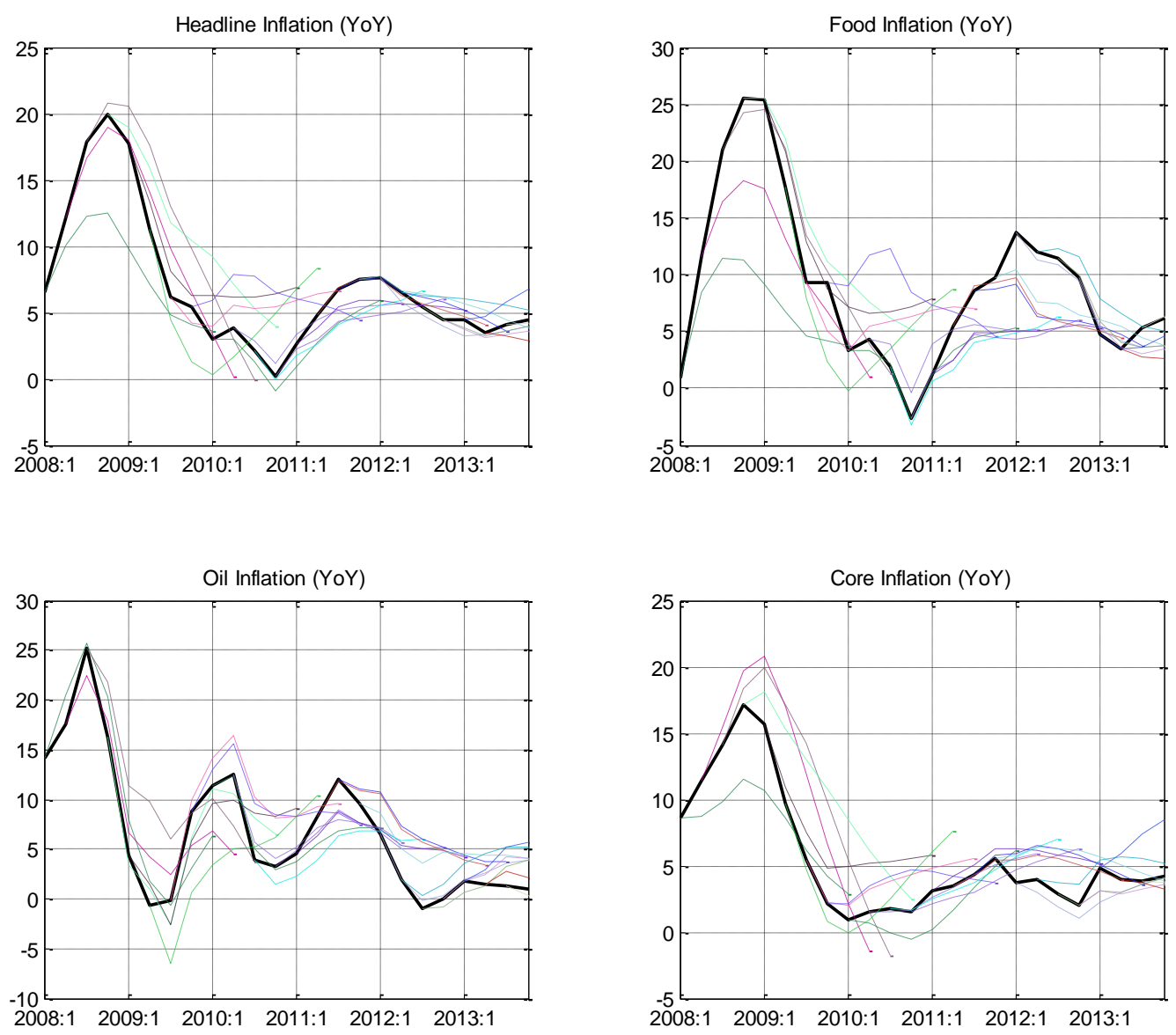
Figure 15: Out-of-sample Forecast of the Main Variables

\section{Forecast - Main Indicators}
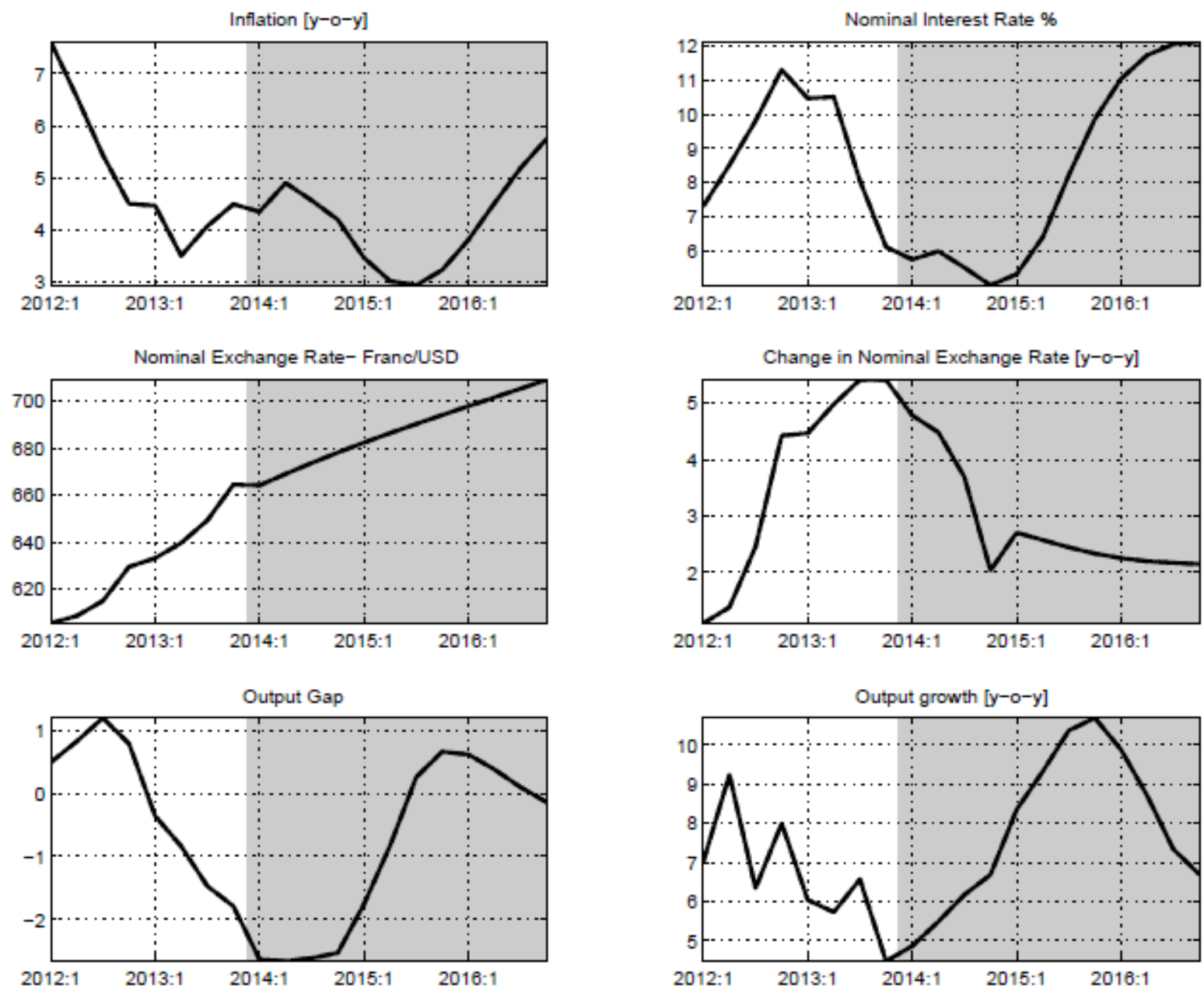
Figure 16: Out-of-sample Forecasts of Main Variables- Continued
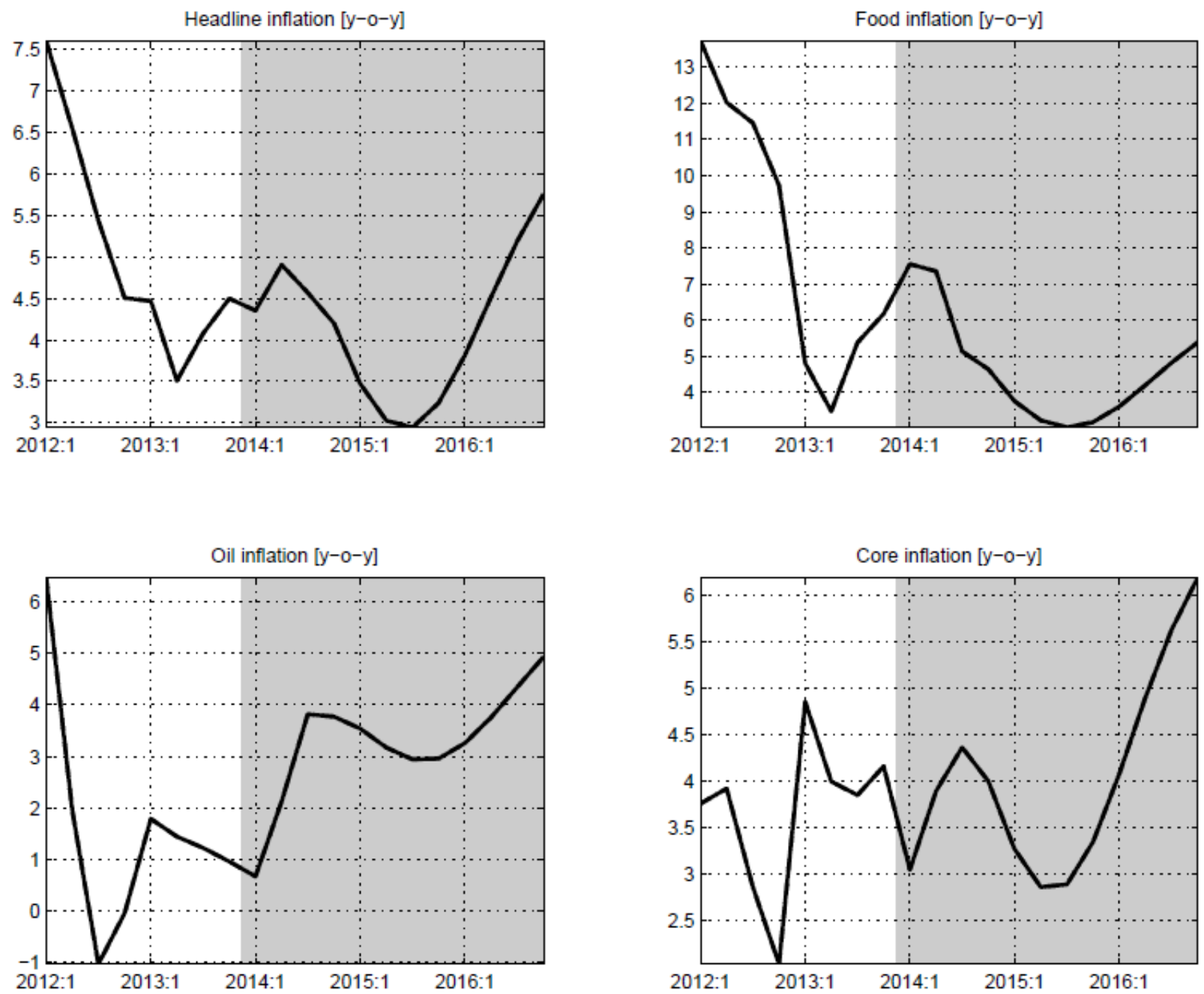


\section{REFERENCES}

Andrle, M. A., Andrew Berg, Rogelio Morales, Rafael Portillo and Jan Vleck. (2013).

Forecasting and Monetary Policy Analysis in Low Income Countries (1): Food and NonFood Inflation in Kenya. Working Paper, International Monetary Fund, Washington, D.C.

Andrle, M. A., Andrew Berg, Enrico Berkes, Rogelio Morales, Rafael Portillo, David Vavra and Jan Vleck. (2013). Forecasting and Policy Analysis Systems in Low Income Countries (2): The Role of Money Targeting in Kenya. Working Paper, International Monetary Fund, Washington, D.C.

Ball, Lawrence. (1994). What Determines the Sacrifice Ratio? In N. Gregory Mankiw (Ed). Monetary Policy (p. 155 - 193). Chicago: The University of Chicago Press.

Benes, Jaromir, Jaromir Hurnik and David Vavra. (2008). Exchange Rate Management and Inflation Targeting: Modeling the Exchange Rate in Reduced-Form New Keynesian Models. Czech Journal of Economics and Finance, 58, No. 3-4.

Benes, Jaromir, Andrew Berg, Rafael A. Portillo and David Vavra. (2013). Modeling Sterilized Interventions and Balance Sheet Effects of Monetary Policy in a New-Keynesian Framework. Working Paper, International Monetary Fund, Washington D.C.

Berg, Andrew, Philippe Karam, and Douglas Laxton. (2006), Practical Model-Based Monetary Policy Analysis-A How-To Guide. Working Paper, International Monetary Fund, Washington D.C.

Berg, Andrew, Luisa Charry, Rafael Portillo and Jan Vleck. (2013). The Monetary Transmission Mechanism in the Tropics. Working Paper, International Monetary Fund, Washington D.C.

International Monetary Fund. (2013a). Annual Report on Exchange Arrangements and Exchange Restrictions. Washington, D.C.

International Monetary Fund. (2013b). Staff Report for Sixth Review under the Policy Support Instrument.Washington, D.C.

International Monetary Fund. (2013c). Staff Report for Seventh Review under the Policy Support Instrument, Request for a Three-Year Policy Support Instrument, and Cancellation of Current Policy Support Instrument. Washington, D.C.

Ostry, Jonathan D., Atish R. Ghosh and Marcos Chamon. (2012). "Two Targets, Two Instruments: Monetary and Exchange Rate Policies in Emerging Market Economies". Staff Discussion Note, International Monetary Fund, Washington D.C. 